\title{
The Poetics of the Symbol in the Kurdish Folktale
}

\section{Hemdad Hussen Bakir ${ }^{1}$}

Received: Jan 21, 2018

\author{
Mohammed Ahmed Hasan ${ }^{2}$
}

Reviewed: Feb 18, 2018
Accepted: Mar 21, 2018

\begin{abstract}
The symbol is a key factor for achieving poeticism in text, which in turn shows the art of text. This research (The poetics of the symbol in the Kurdish folktale) came as an attempt to study the role of the symbol in the technical realization of the ancient texts such as folklore.The research consists of two parts. The first is the title of "The Concept of Poeticism" We tried to clarify this term in the theoretical aspect, and this is the reader's knowledge of the role of this concept in the texts. The second section, which was the title (the poetics of the symbol of the Kurdish folktale) and explained three types in the symbols: the historical symbol, the legendary and religious. We tried to stand in these three types in the texts of the folkloric story with its semantic implications, with the most important findings of the research and a list of sources that we have benefited from during this study.
\end{abstract}

Keywords: Poetics, Kurdish Folktale, Symbol, Folklore

\section{Recommended citation:}

Bakir H. H. \& Hasan M. A. (2018). The poetics of the symbol in the Kurdish Folktale. International Journal of Kurdish Studies 4 (2), 336-349.doi: 10.21600/ ijoks.454451

\footnotetext{
${ }^{1}$. Prof.Dr. Department of Kurdish Language, College of Education, Salahaddin University, Erbil, Kurdistan Region-Iraq. Email: hemdad.bakir@su.edu.krd

2. Lecturer, Department of Kurdish Language, College of Education- Shaqlawa, Salahaddin University, Erbil, Kurdistan Region-Iraq. Email: Mohammed.hasan@su.edu.krd
} 


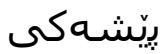

رهمز وهكو تهكنيكيّك هوّكاريّكى سـرهكييه بوّ هيّنانهدى شيعرييهت له دهقدا، ئهم شيعريهته

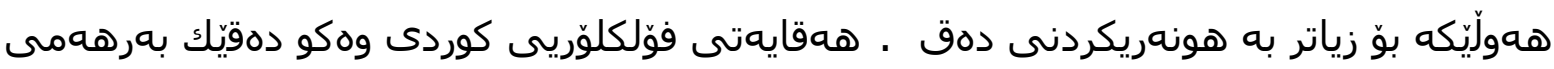

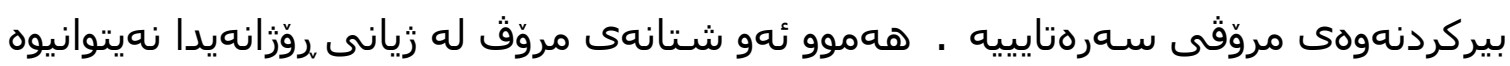

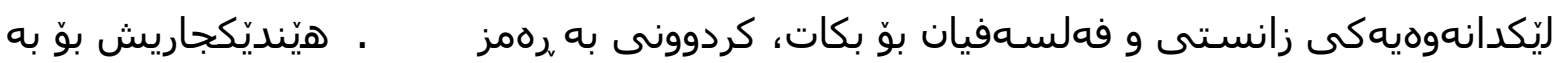

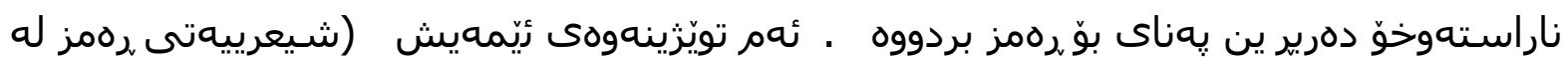

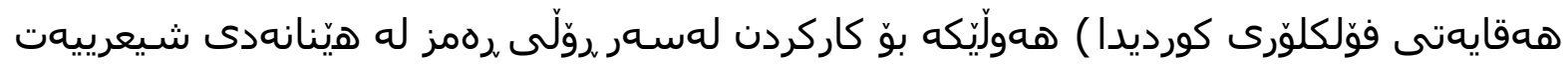
له دهويّكى كوّنى وهكو همقايهتى فوّلكلوّريى كورديدا.

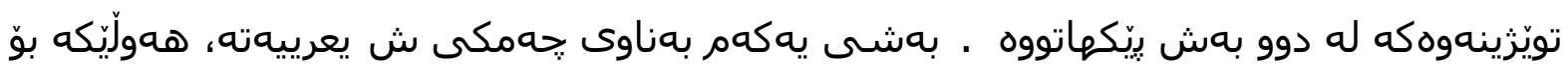

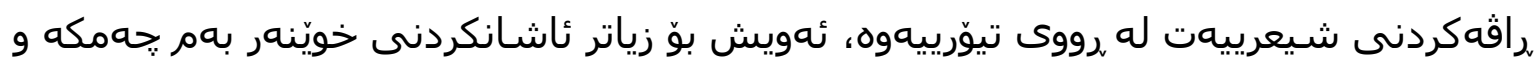

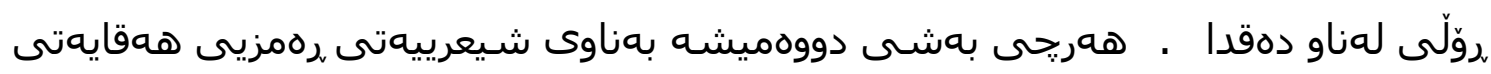

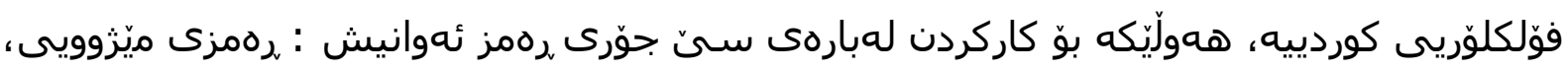

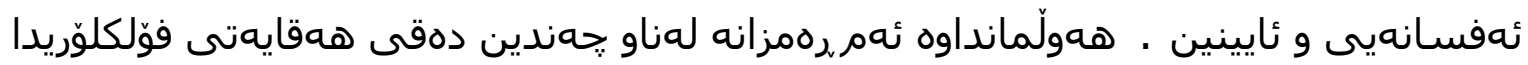

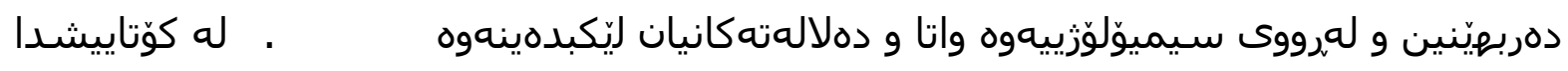
كهيشتووين به جهند ئهنجامينك.

بهشى يهكمر: :حمككى شيعرييهت

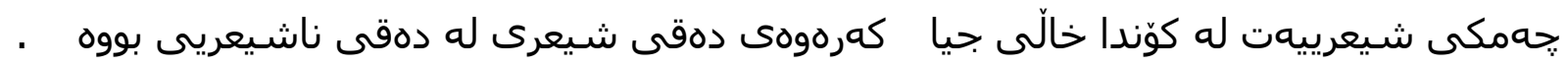

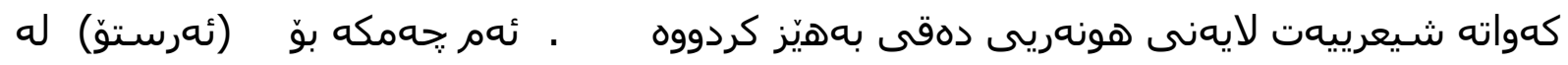

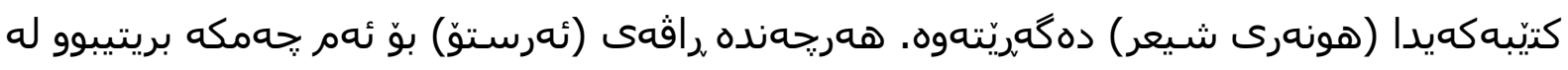

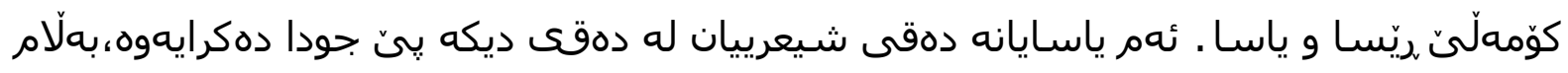

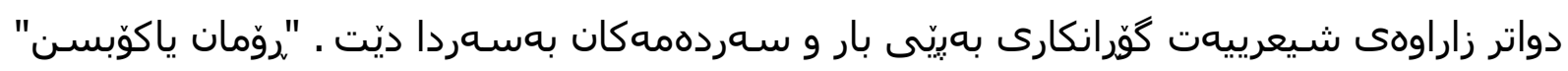
شيعرييهت بِيْوهست به زمان دهكاتهوه، هاوكات شـيعرييهت بايهخ به واتا لهناو زماندا دهدات

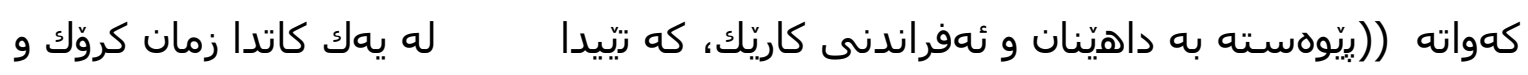

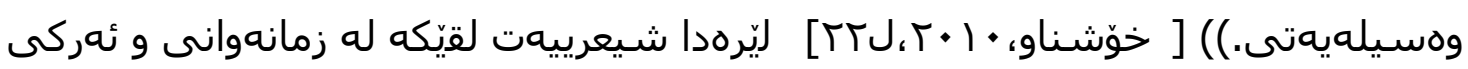

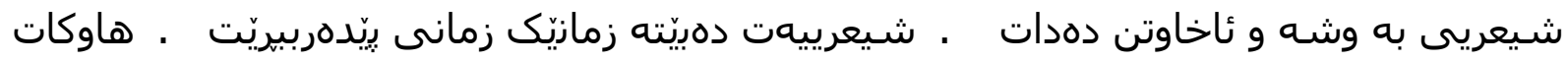

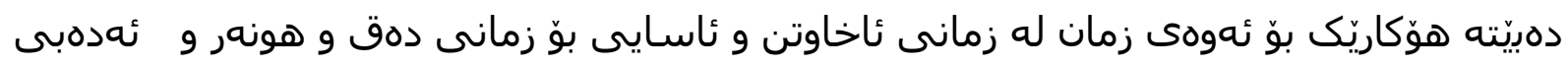

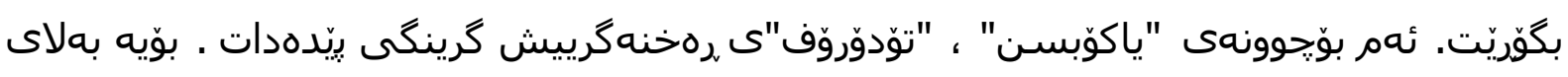

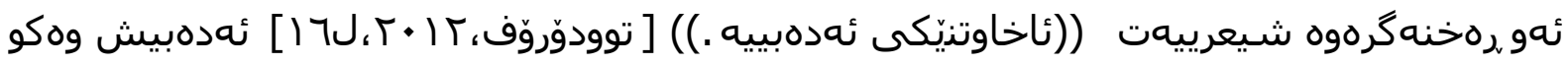

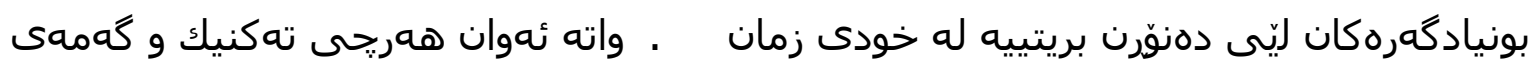

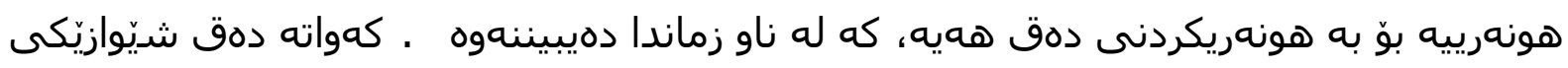




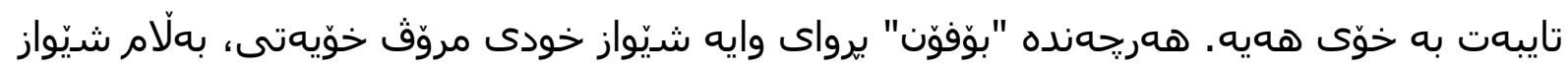
دهكرى به ريّيهكى نووسينيش ههزمارى بكهين، كهواته شيّواز ليّرهدا دهريّته دياريكردنى لادانى زمان و ئاستى شيعرييهت.

ليّرهدا جيِى خوّيهتى بيرسـين، ئايا شـيعرييهت تهنيا لهناو دهقى شيعريدا ههيه؟ ئايا تهنيا زمانى

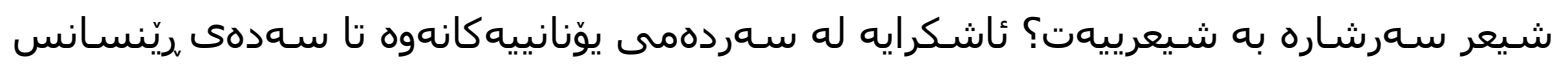

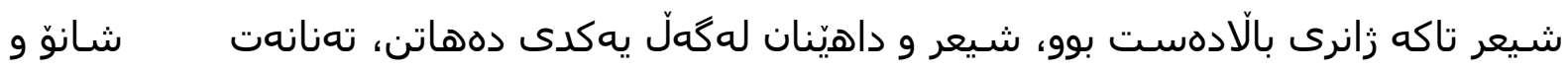

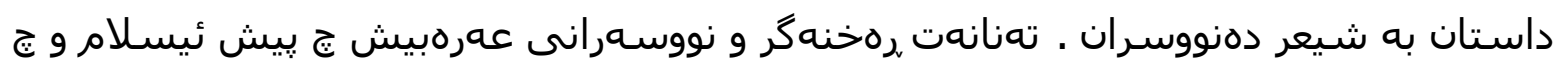

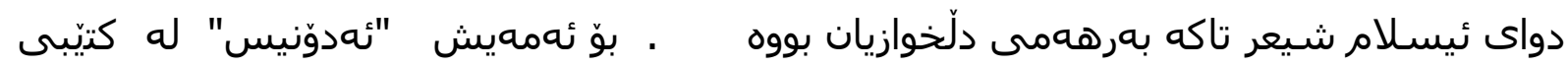

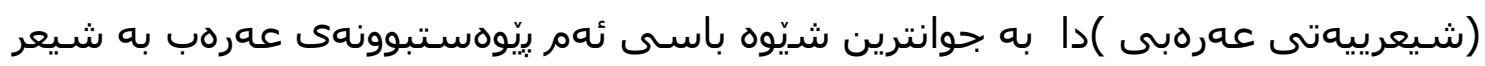

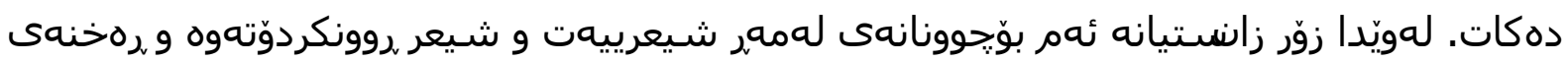

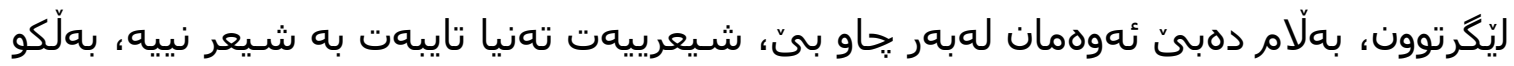

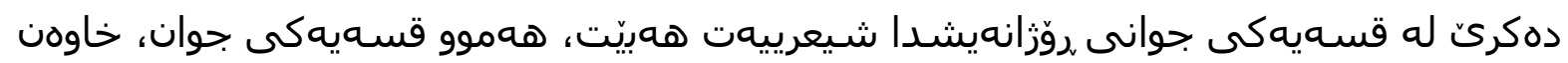
ريتم و شـيعرييهته.

شيعرييهت و سيموّلوّريا بِيِوهندييهكى يتهو لهزيّوانياندا ههيه، تجونكه ههردووكيان بِيْوهندن به

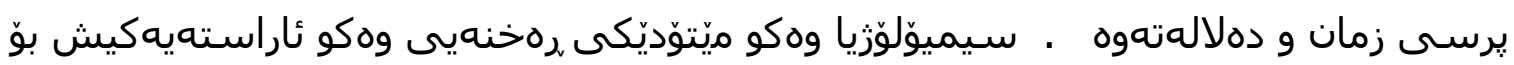

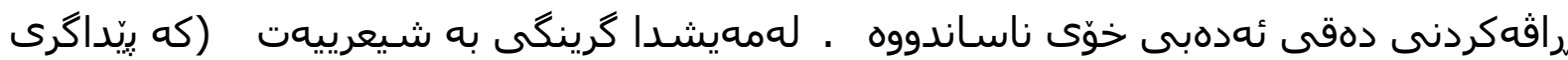

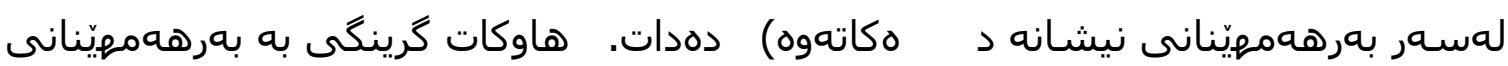

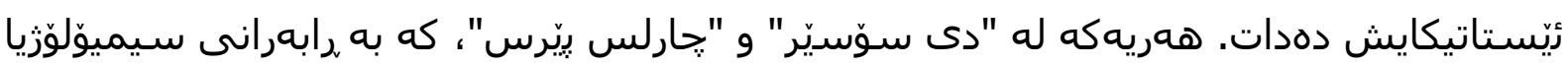
دادهنريّن، بنهمايان بوّ راقهكردن و بِينكعاتهى دهق ئيشـردنه لهسهر شيعرييهت . ههردووكيان له

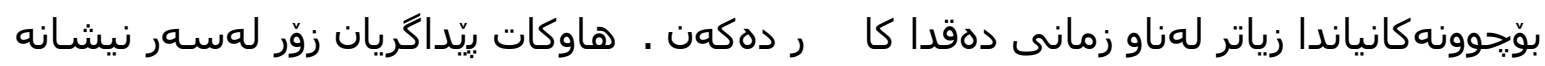

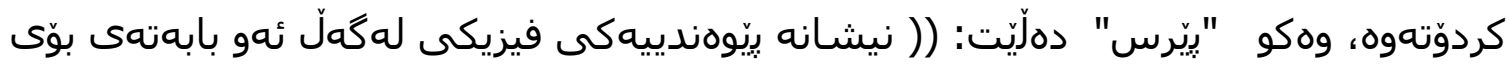

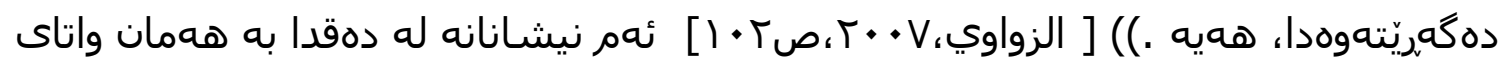

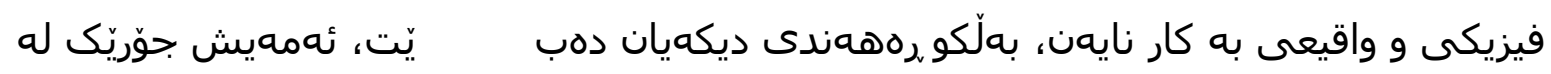

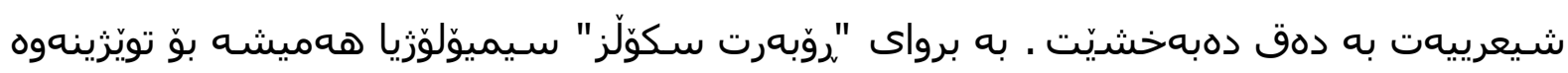

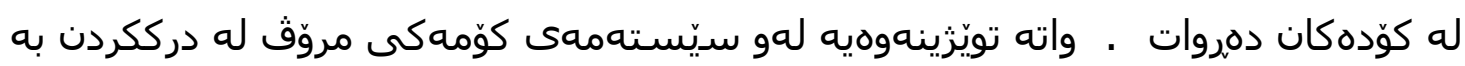

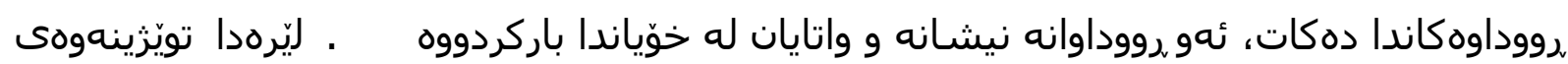

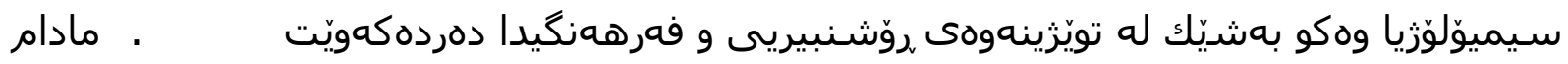

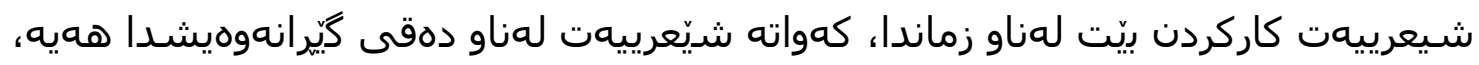

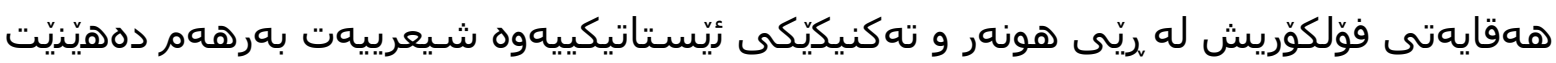
:

بهشـ دووهمر: شيعرييهتى ،رهمز له همقايهتى فوّلكلوّريدا 


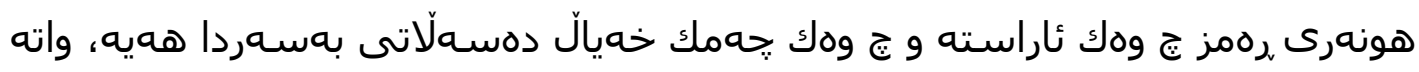
كوزارشته له بيريّك به ريّيهكى ناراستهوخوّ، بهشيْوهيهكى ديكه ئامازه بوّ شتهكه دهكريّت،

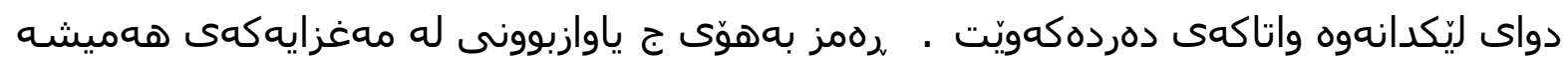

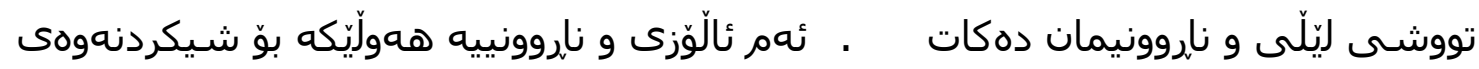

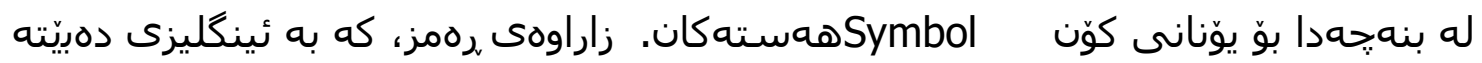

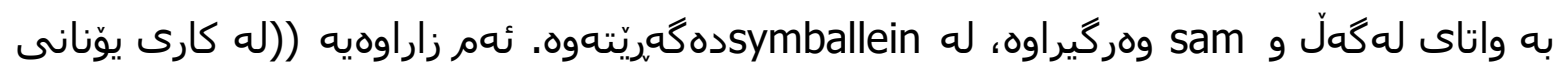

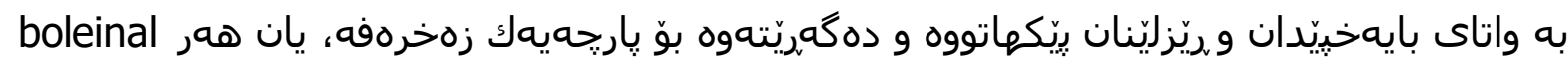

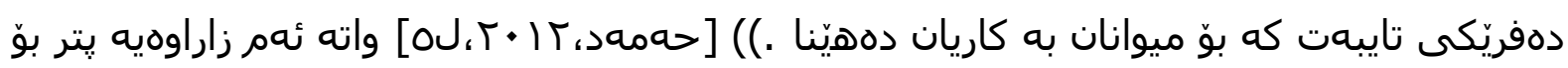

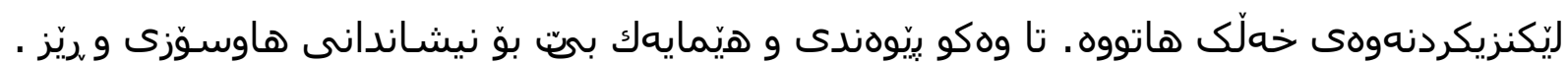

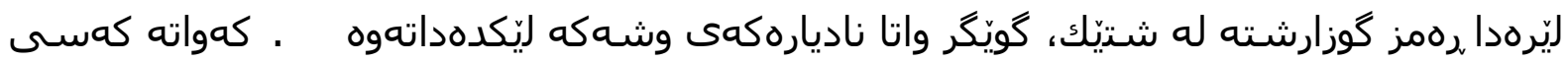

زيّرهر واتايهكى شـاراوهى له يشت وشـهانهوه شاردوّتوه، ئهويش به هوّى دهستهوازَه و

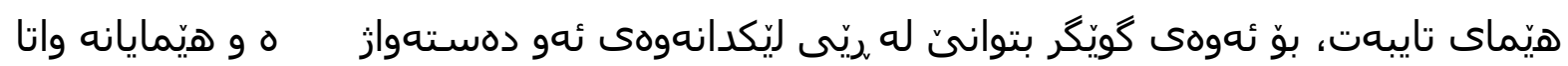
شاراوهكهى رهمزهكه ئاشكرا بكات . رهمز ((دهربرينى دهنكيكى نزمه وهك بهجيهدوان، هاوكات

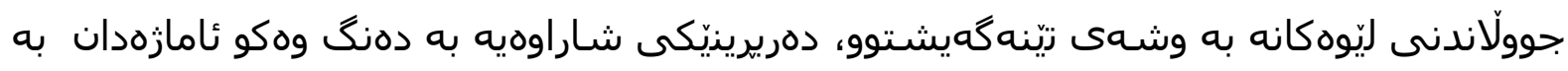

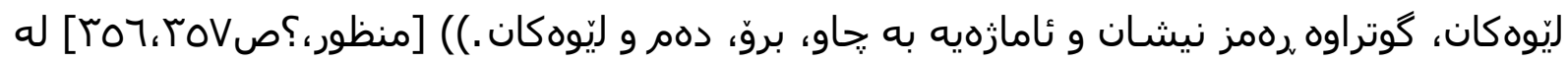

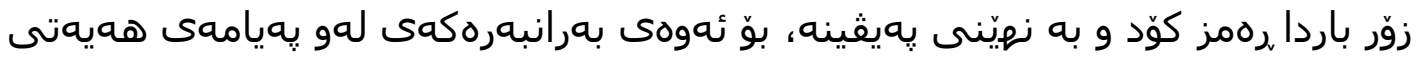
بكَيهنين، كه ناتوانى به راستهوخوّ دهريبيريّت.

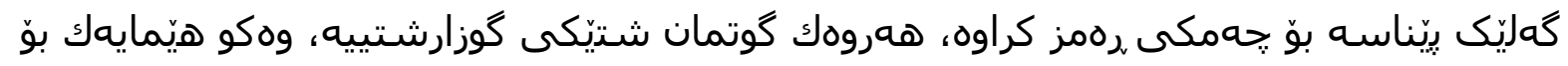
شتيّكى ديكهى جودا له واتا فهرهه نكييهكهى. تهنانهت دهروونناسيّكى وهكو "كارل كُوستاف يوّنگ" به هوّكاريّكى دركيّكردنى دادهنيّ، جحونكه مروّث ئارهزووى له هيّمايه، دهبينين ههموو

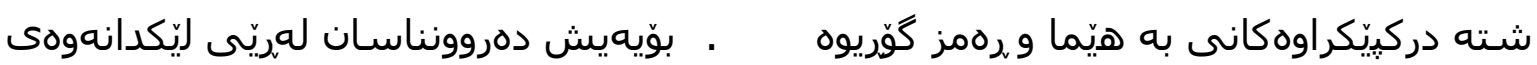

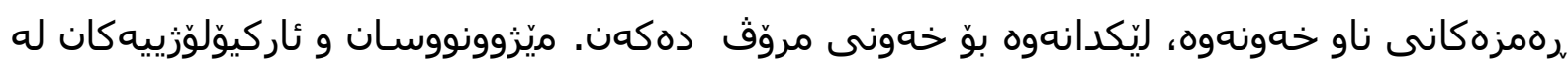
ريّى ،رهمزهكانهوه دهيانهوك زانيارى لهسهر مروّق و شارستانيهته كوّنهكان دهستبخهن.

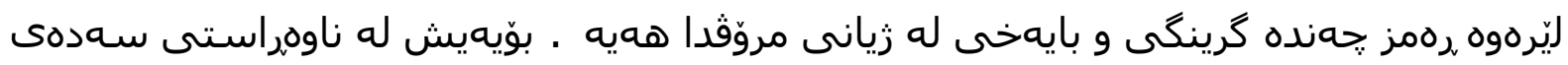

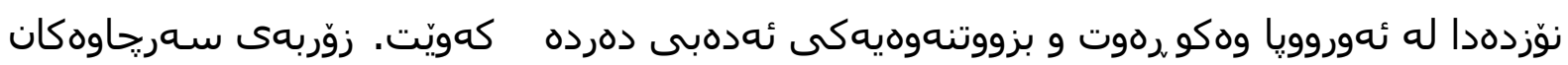

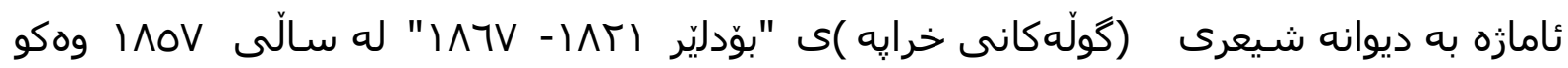
سهرهتاى دهركهوتنى سـيميبوليزم دهكهن ـ ((به نوّرينى بوّدليرهوه دنيا بِيشهيهكى ليّوان ليّوى

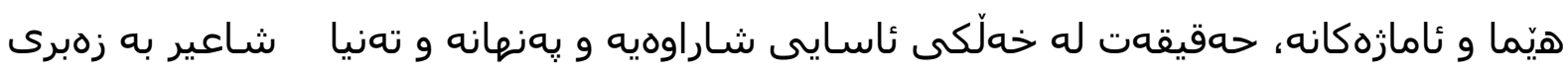
ئهو ئيدراكهى ههيهتى، له ريّكَى تهفسير وراقه و شـروّقهى ئهو هيّما و ئامازّانه ههستى

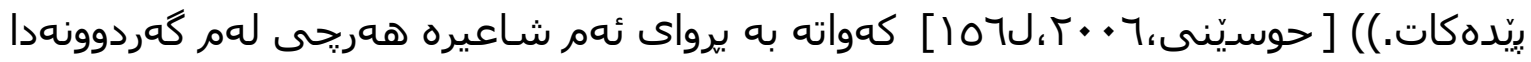
ههيه، رهمزه. ئهو درهمزانهيش ههموو كهس ناتوانى ههستيان يُن بكات و ليّكدانهوهيان بوّ بكا،

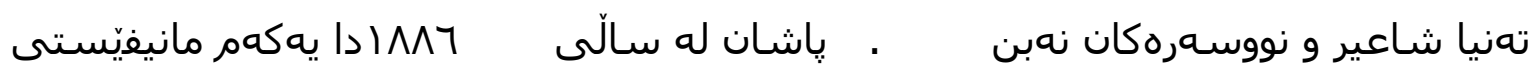


سيمبوليستهكان له نووسينى "زان موّريّياس" بلّاودهريّتهوه. بوَيهيش ((لاى سيمبوليستهكان،

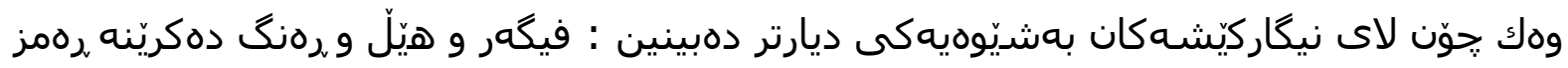
نهى تهنيا سيّبهر و،رووناكى بهشيِوهيهكى واقيعيانه به كار بيّن و تهنيا تهعبير له ههست بكهن

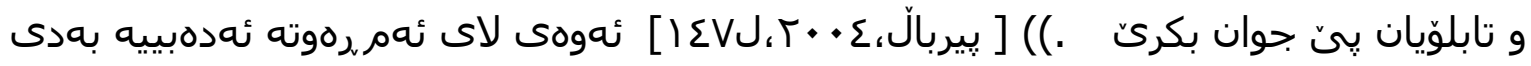

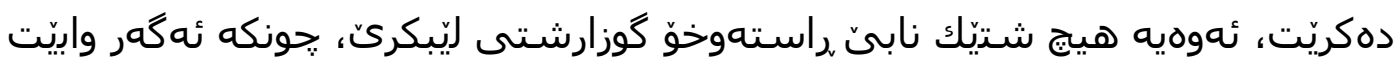

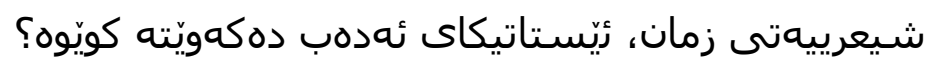

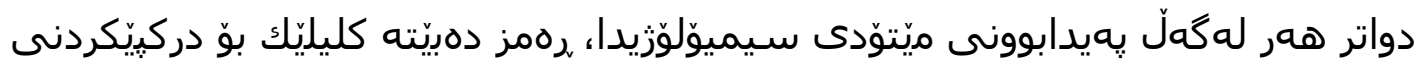

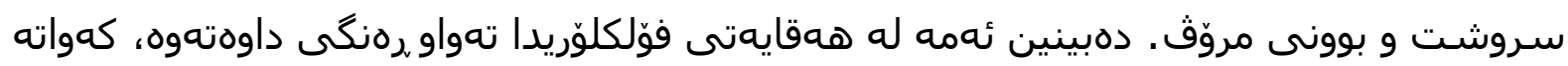

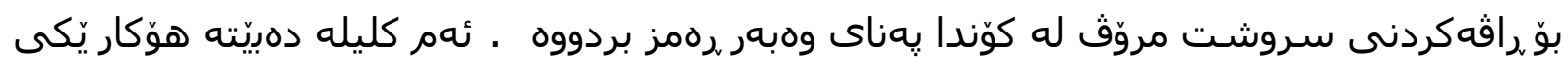

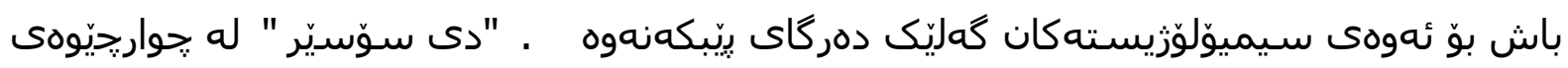
وانهكانيدا لهبارهى زمانهوانيدا، ئامازهى به دال و مهدلوول كردووه ((دال بوّ نموونه وهكو (دار)

هيج سيفهزيّكى مهدلووكه له خوّيدا هملّناكريتت، تاكه بههانهيهى بوّ ئهم ناونانه تهنيا

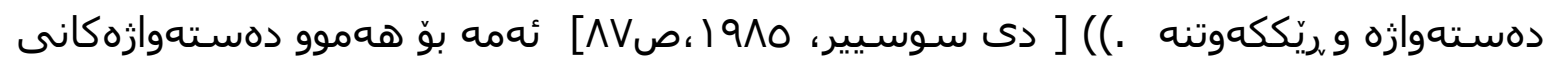

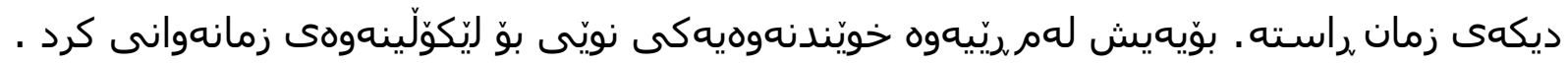

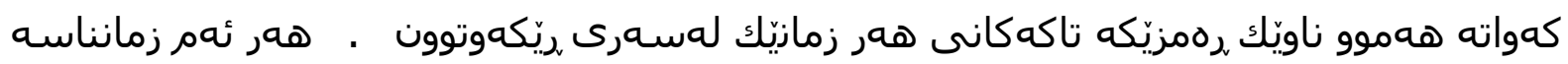
ئاماره بوّ جوَريّكى دى كه له دهلالهتهكان دهكات، ئهوانهى جكَه له مهدلوولى ريّككهوتنهكه، مهدلوولى ديكهيان ههيه. بوّ نموونه (تهرازوو) دهلالهته له داديهروهرى، (كوّتر)ى سيى دهو دهلالهته

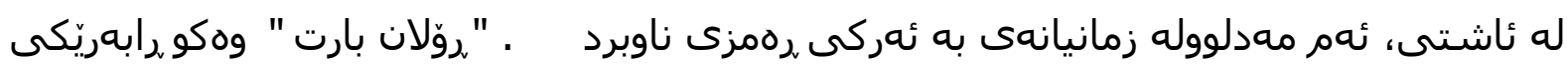

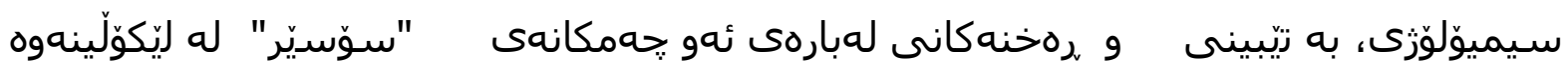
زمانهوانييهكانى بهرههمى هيَنان، خويّندنهوهيهكى ديكهى بوّ نيشانهناسى و رهمز بهوتايبهت

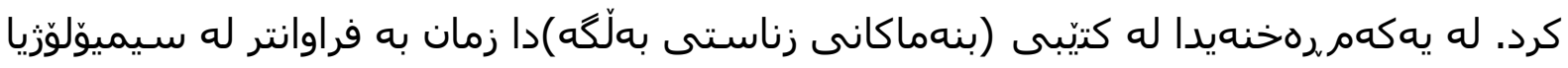

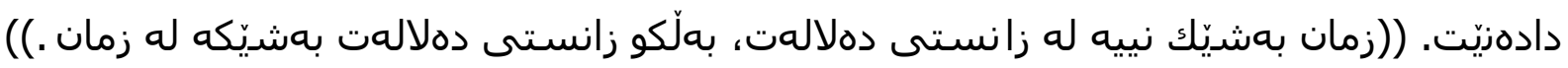

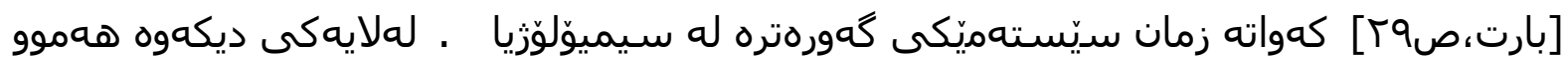

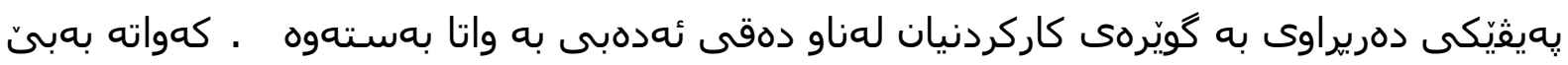

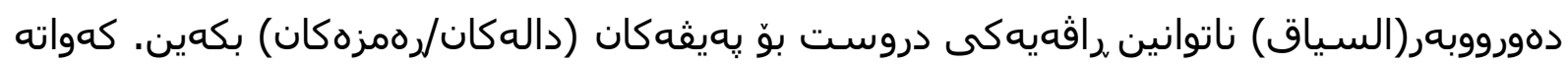

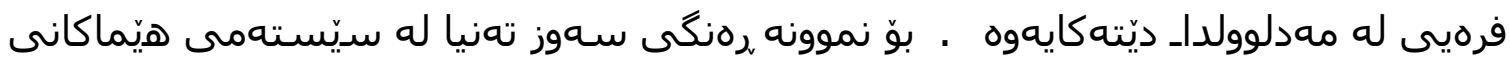

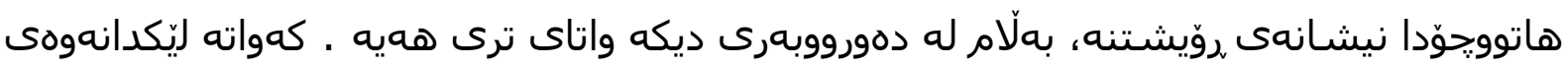

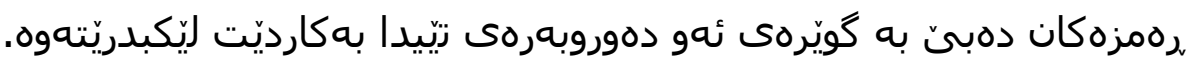

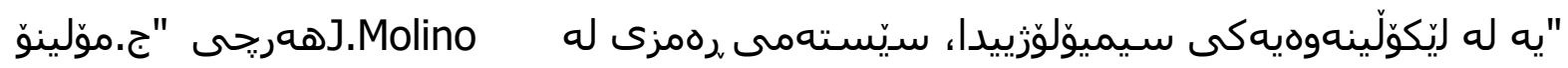

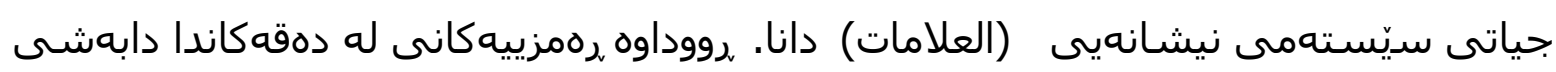

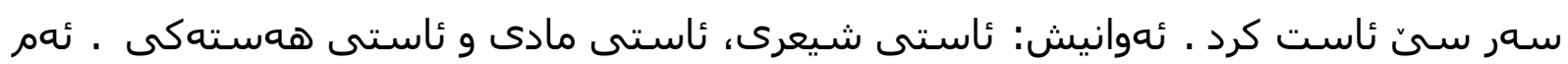

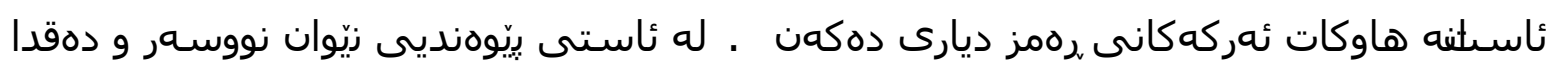




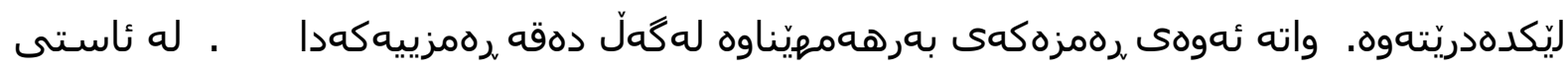
دووهمدا تهنيا بهرههم و دهقكه كارى لهبارهوه دهكريّت . له ئاستى سيّيهمدا تيشك دهخريّته سهر دهق و بِيْوهندى لهُّلّ خويّنهر يان وهركردا.

رهمز له دهقى كيّرانهوهييدا خوّى لهناو همموو توخمهكانى دهقى كيّرانهوهيى، يان همقايهتدا

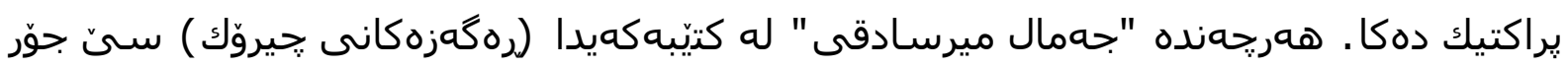

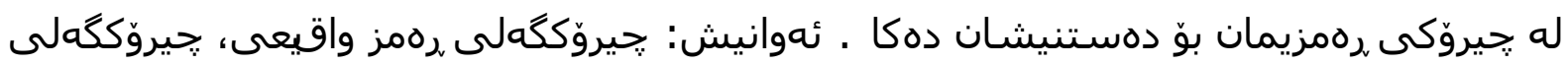

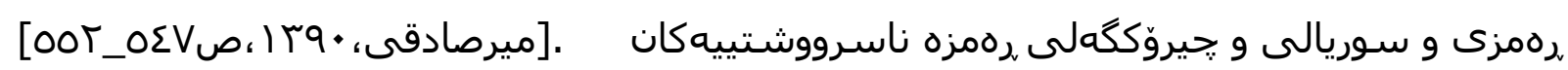

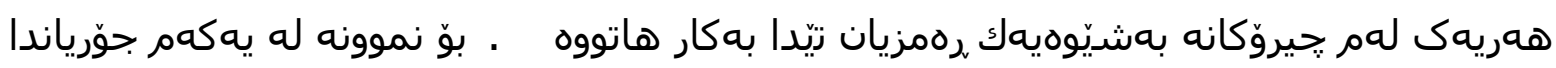

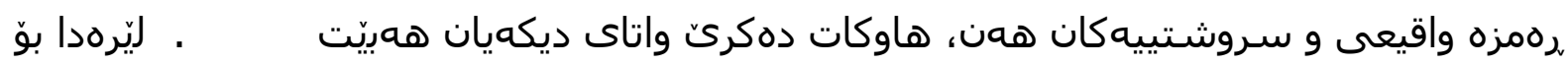

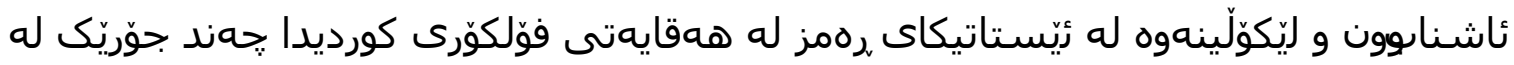
رهمز يراكتيك دهكهين:

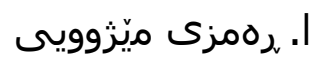

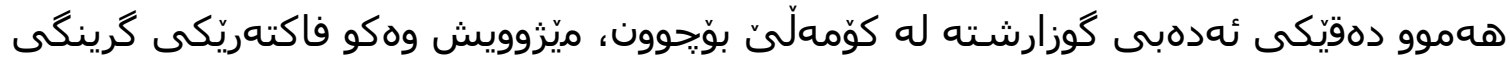

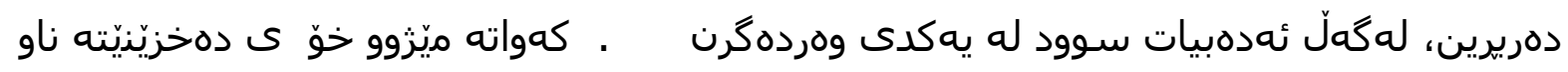

ئهدبيات بهتايبهت لهلايهن ئهو ميللجتانهى همميشه داخيركراو و زيّردهستهبوونه نهيانتوانيوه

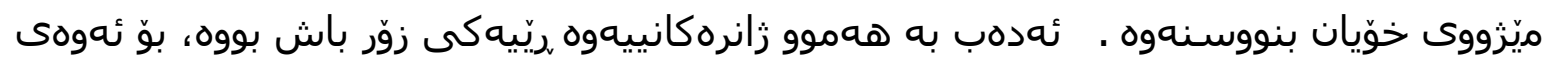

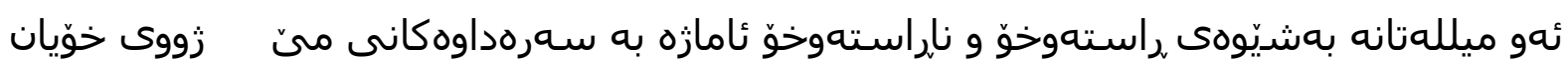
بكهن. هaريحهنده همقايهتى فوّلكلوّريى كوردى، وهكو هى هaموو نهتووهكانى ديكه بهرههمى

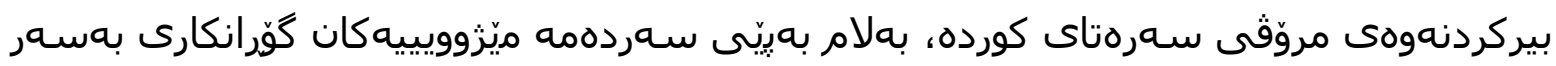
درووداو و كهسـكانى ناوى هاتوون. ليّرهدا زوّر لايهنى ميّزوويى ههيه وهكو رهمز و دهلالهت خوّ ى

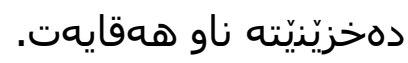

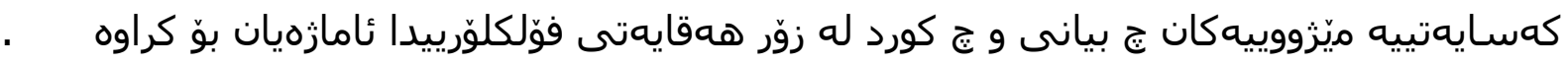

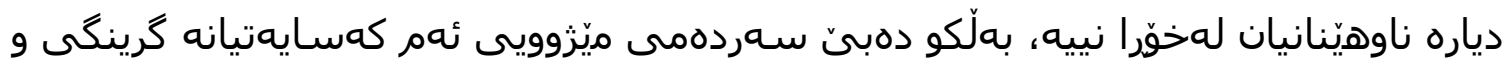

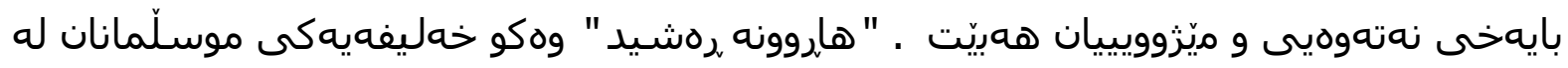

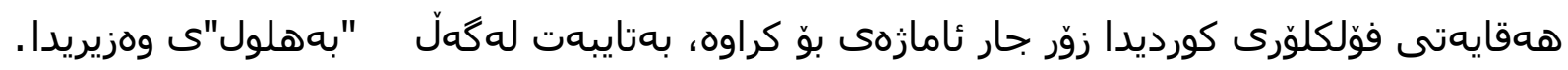

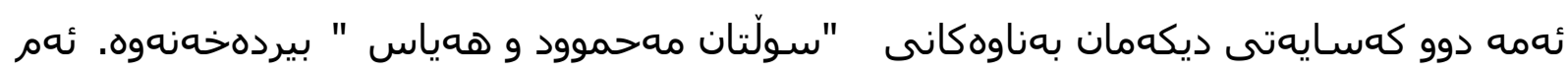
كهسايهتيانه له همقايهتدا زوّر بايهخيان بِيّدراوه، بهتايبهت وهزيرهكانيان، كه به مروّوثى عاقلّمهند

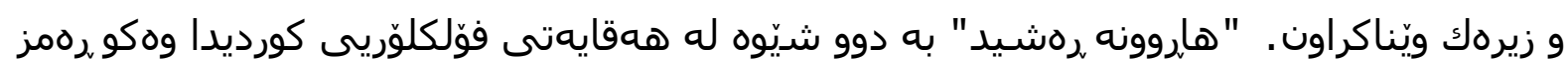

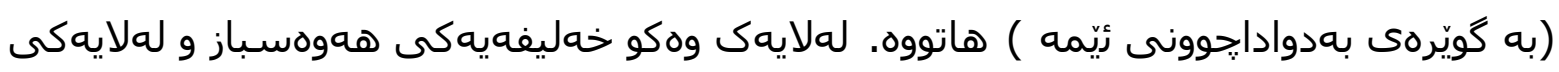

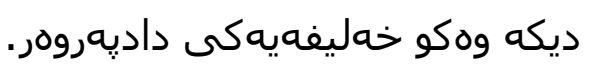

له ههقايهتى (سليّمانين خولامى وهز يرى)، ئهم كهسايهتييه ميّزووييه وهكو خهليفهيهى هووهسباز و :حاولهدهر ويّنا دهكرى. ((هارونه رهشيدى وهزيرهى همبوو، زنا وهزيرى كهلهكا جوان 
بوو، روّزهكى هارون رهشيد ل بهر يهنجهركا ديوانا خوّ بوو، :جاقى وى ب سهربانى قهسرا

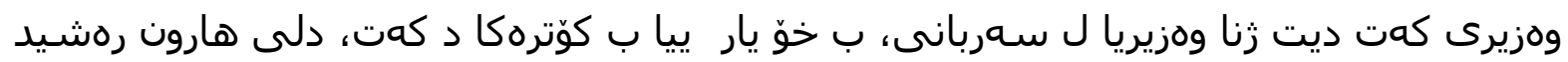

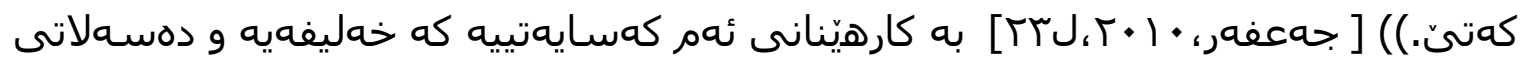
ههيه، رهمزه بوّ شيّوازى زيان و دهسهلاتى ئهو كهواته ئهم خهليفهيه زوّر حهزى به زن و كهنيزه و كوّشك و تهلار كردووه . بوّيهيش لهناو ههموو خهليفهكانى ئسلامدا زياتر باسـى ئهم دهكريّت، زوّرترين درهنگدانهوهيشى لهناو ئهدهبياتدا ههبووه.

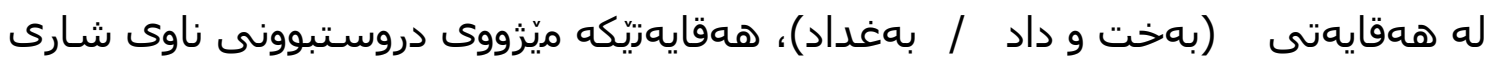

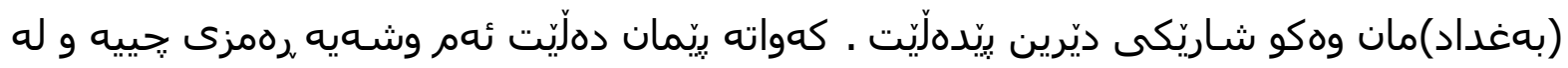

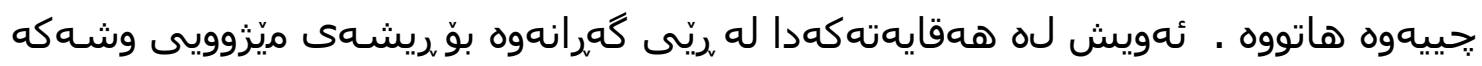

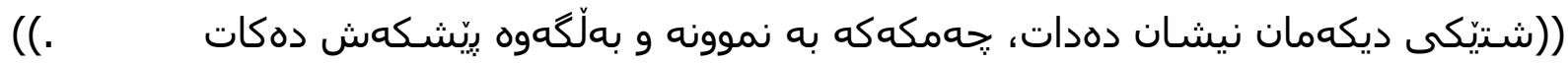

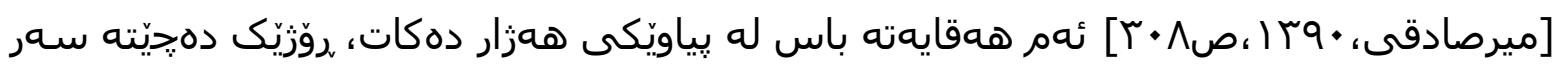

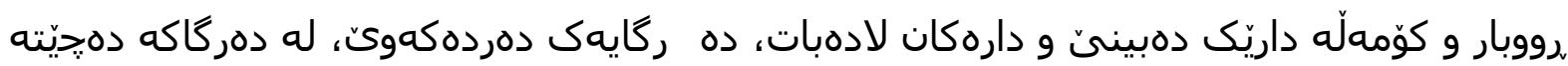

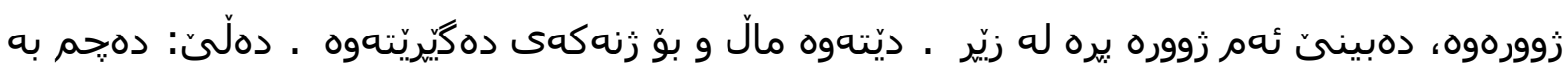

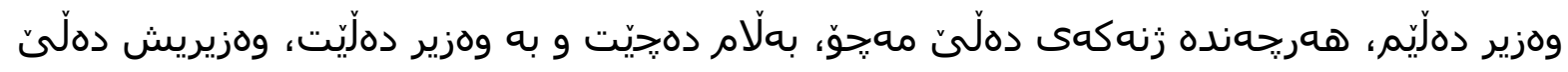

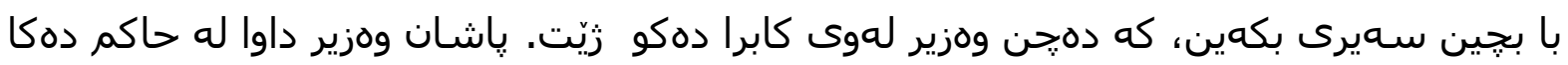

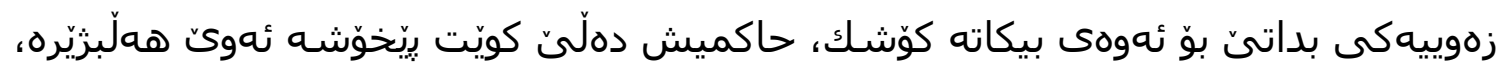

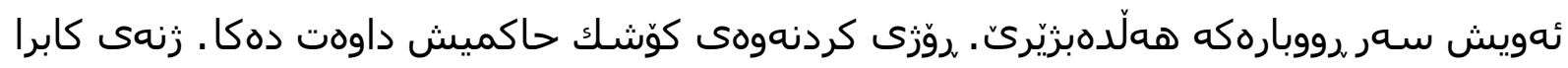
كوركانى ناو دهزيّت تهخت و داد، لهو يروّزدا هاوار دهكا تهخت و داد، حاكميش كه كويّى لهوه

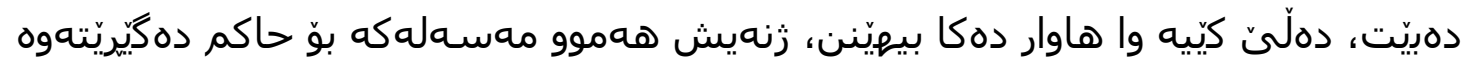

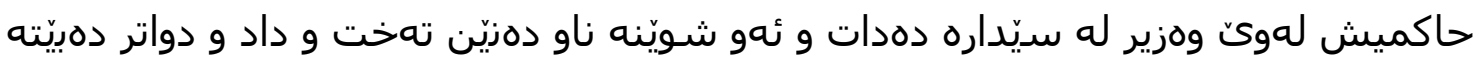

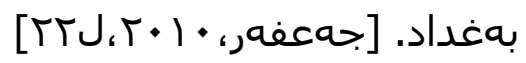

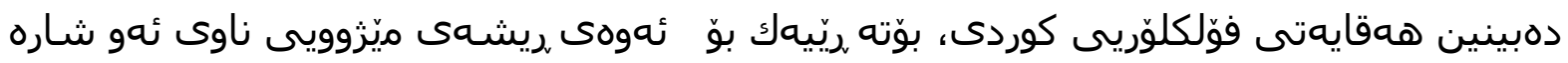

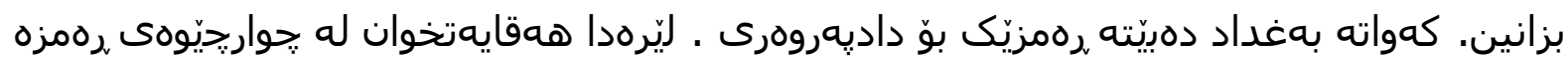

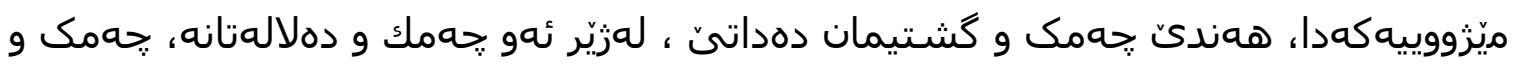

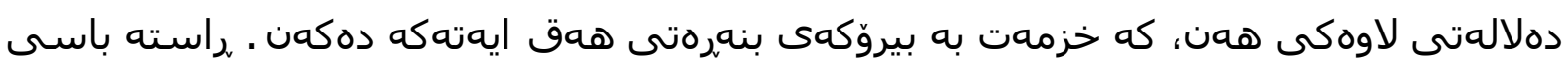

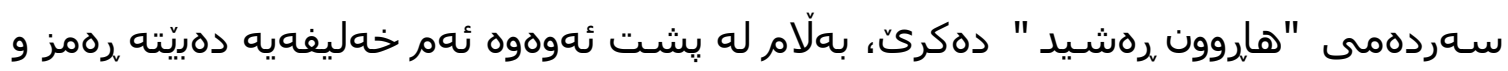
دهلالهت بوّ ئهو خهليفانهى به دواى ههوهس و ئارهزووى سيّكسييهوهن و بههوّى سهرقالّيان

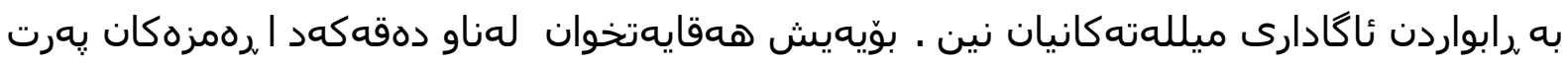

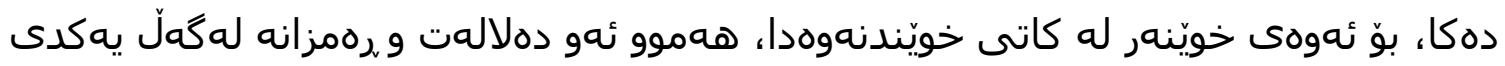
كرى بداتهوه، بوّ ئهوهى به رهمزله گشتييهكه بكات . كهواته يهكبوونى دهلالهت لهناو دهقدا له

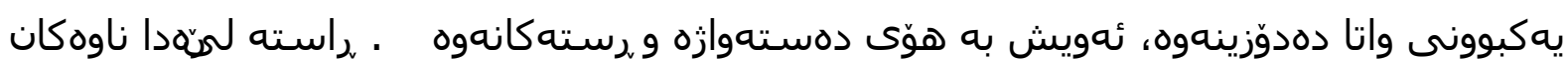


(هاروونه رهشيد ) و (بهغداد) ناوى واقيعيين، بهلّام له يشت خوّيانهوه رهمزى ديكهيان

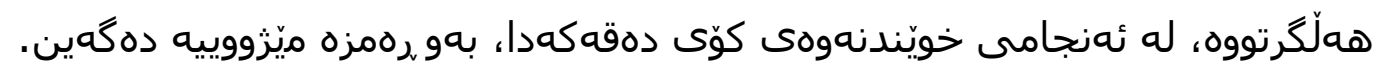
ب. رهمزى ئهفسانهيى

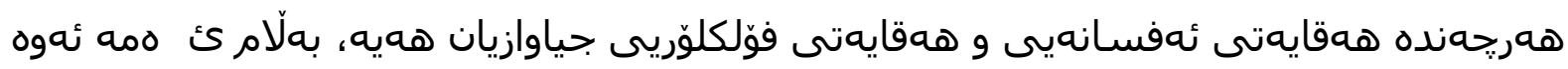

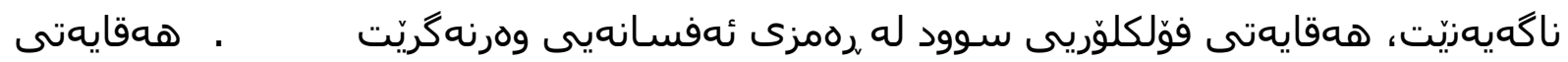
فوّلكلورييش له زوّر باردا يهنا بوّ ئهفسانه دهبات، جحونكه ئهويش بهرههمى بيركردنهوهى مروّقى

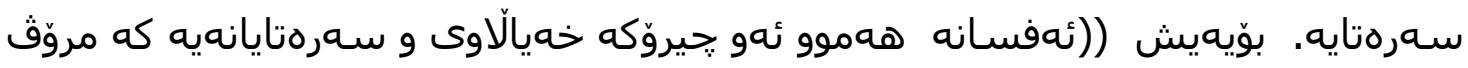
دروستى كردو ون، بهرانبهر به دياردهكانى سـروشت كاتِّك مروّف نهيتوانيوه كوزارشت له له

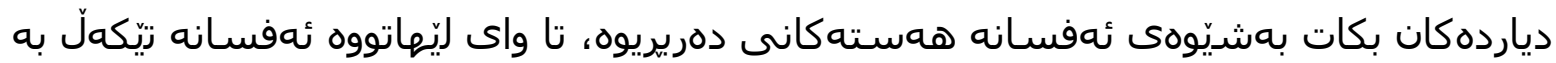

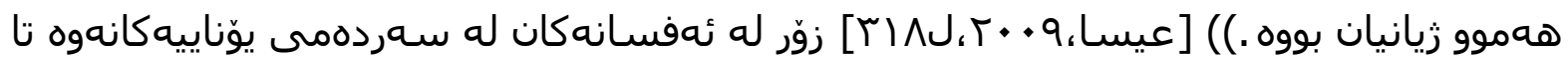
ئيّستا، بوونهته رهمز بوٌ دهريرينى لايهزيّكى زيان، ئهفسانهيش له كوّى بوارهكانى رياندا وهكو ئايينى، ميّزوويى، ئهدبى....تاد هون.

له همقايهتى (ئهو ديّوهى ويستى كورى ئاشهوان بكوزيّت )، باس له كوره ئاشهوازيّك دهكا،

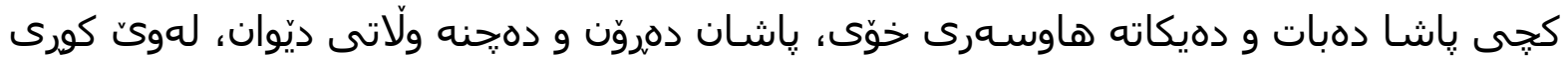
ئاشـوان ههشت له ديّوهكان دهكوزيّت و يهكيان خوّى حهشار دهدات .دواتر ديّوه و رنهى كوره ريّكدهكهون كوره بكوزن. تجهنده زنه بههانه به كوره دهكرى و داواى شتيّك دهكا، كه له شويننى

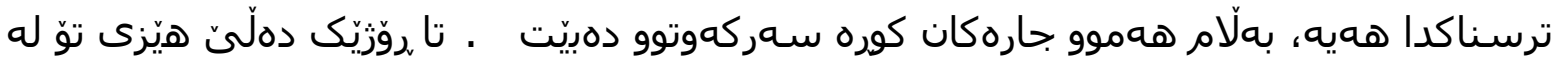

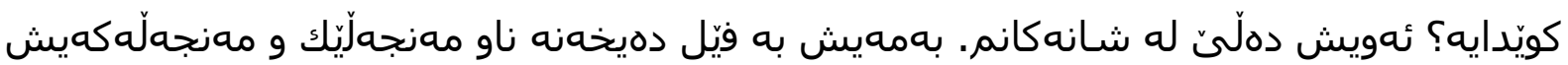
به رووباردا دهده . جادووكهريّك دهبى، كانى و ئاوى حهياتى له مالّكهيهتى، روووبارهكه به

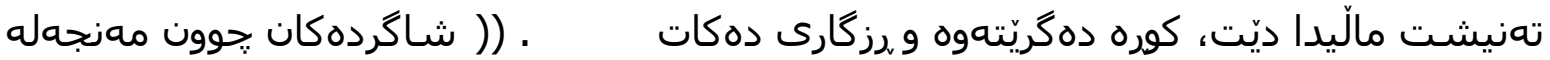

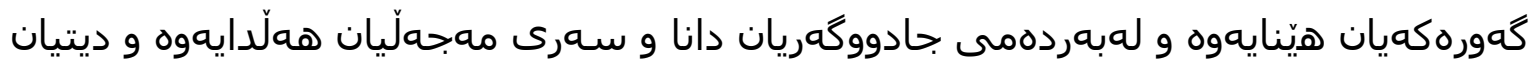

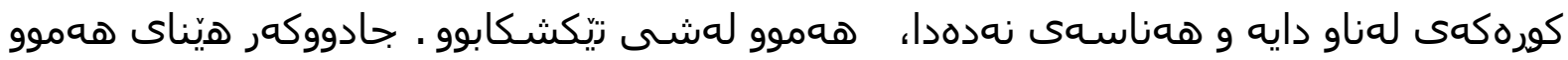

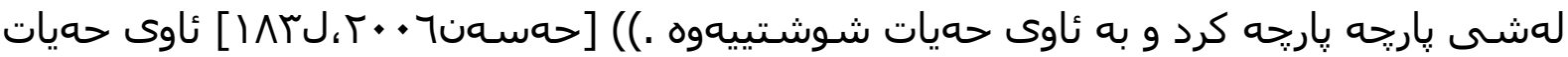

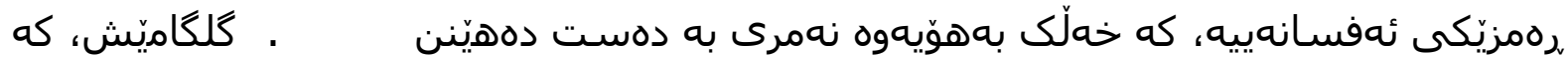

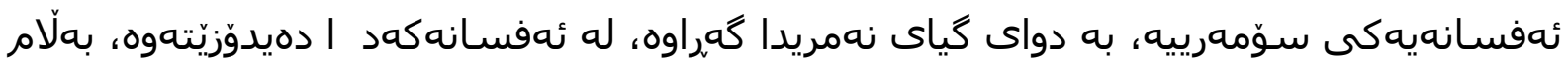

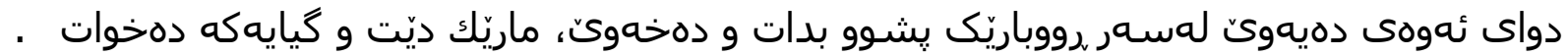
به كَّرانى سهردهم و زيانى مروّقهان ، بهتايبهتى لهگَّل هاتنى ئايينى ئيسلام ئهم كياى

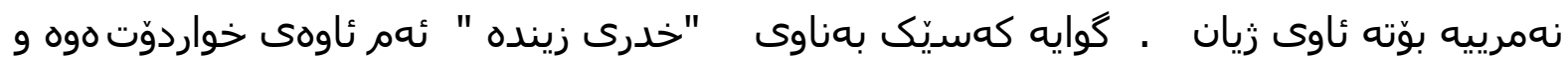

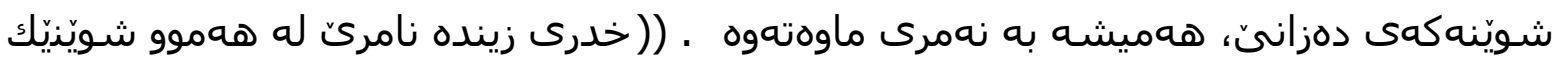

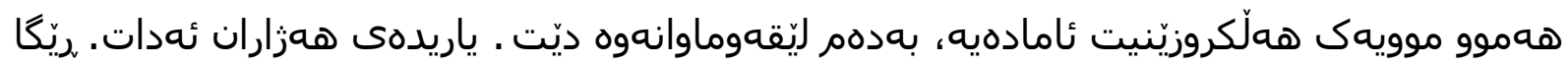

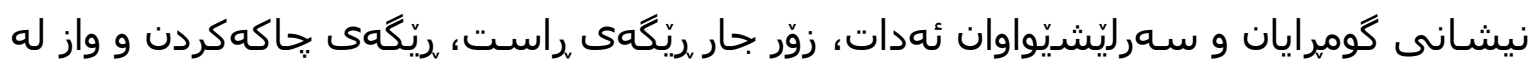

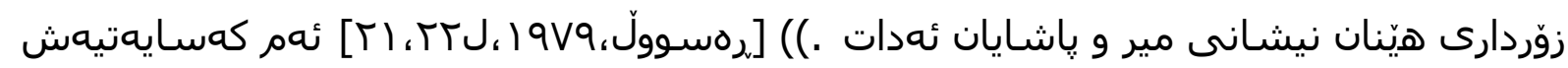


وهكو رهمزى نهمرى و مانهوه لهناو هوقايهتهكاندا ههيه .ئهركى ئهم كهسايهتييه ههميشه

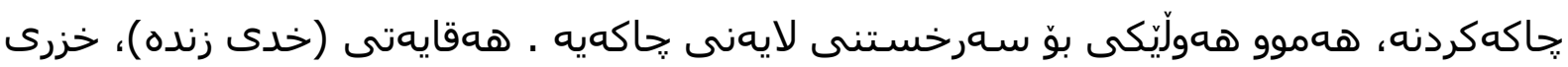

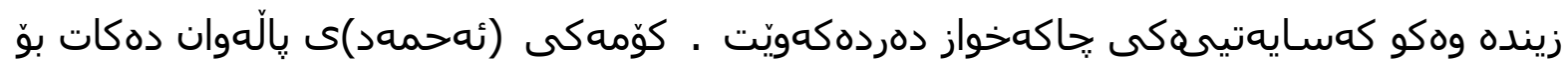

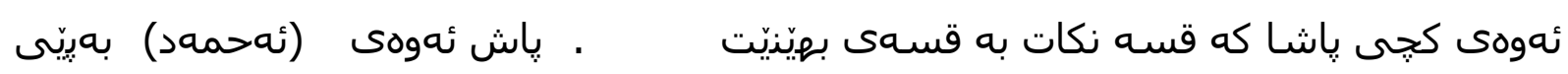

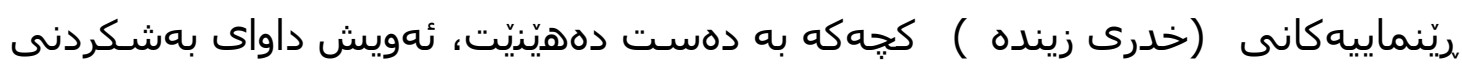

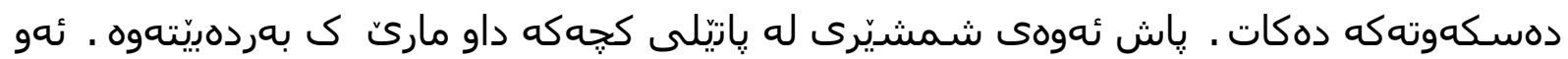

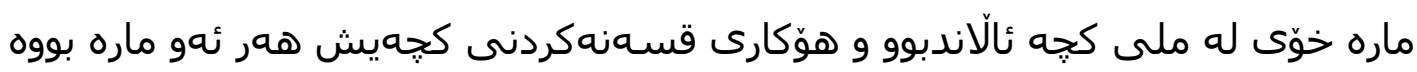
((يياوهكه وايكوت و لهبهريحاو بزر بوو. ئهو حهله ئهحمهد زانى ئهوه خدرى زيندهيه . ئيتر دهستى

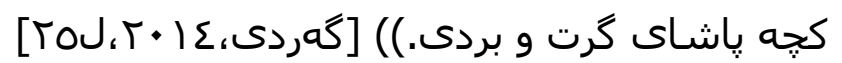

لهم همقايهتدا جودا لهوهى دوو بهرهى پاكه و خرايهمان ههيه: كهسايهتى (خدرى زينده) وهكو بهرهى جاكهخواز دهردهكويّت . رهمزيّكى ئهفسانهييشه و ئاوى زيانى خواردوّتهوه، ئهمهيش بوّ

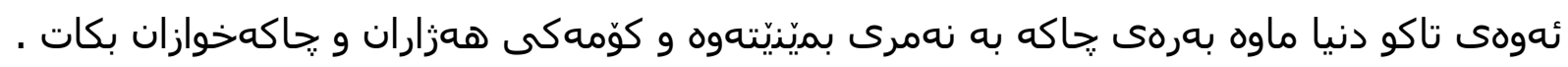

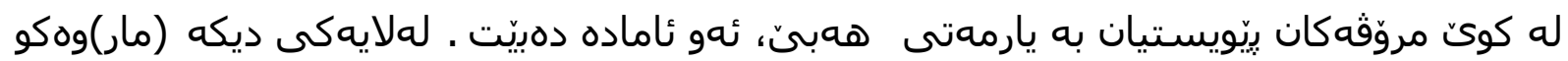

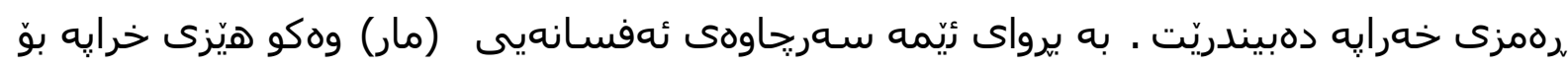

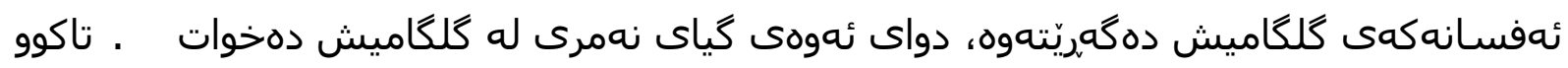

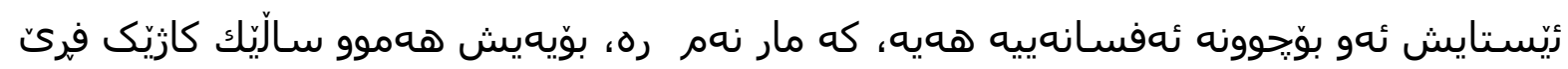

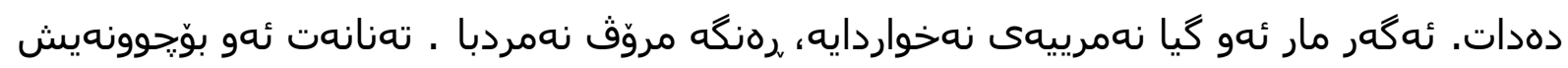
ههيه، كه مار بوّته هوّى فريودانى حهوا له بهههشت و وايكردوه سيّوهكه بخوات، بهمر

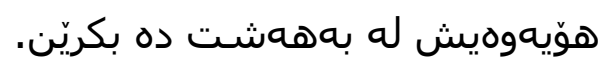

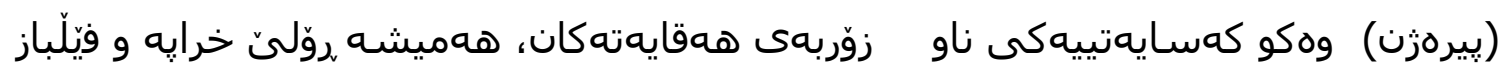

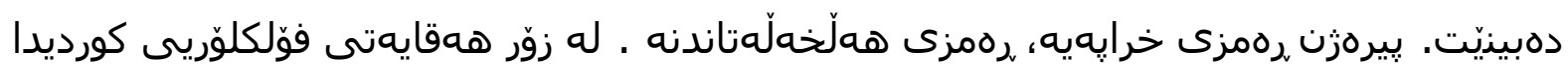

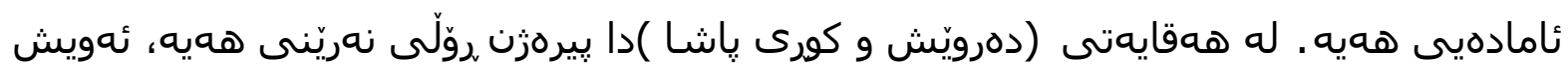

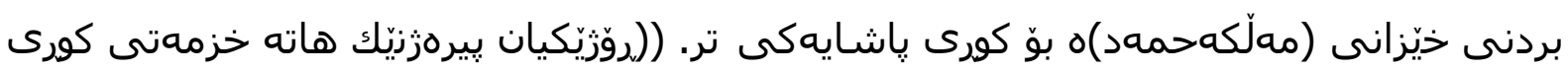

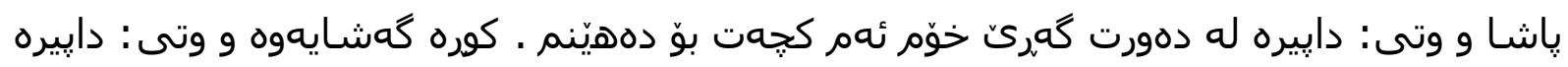

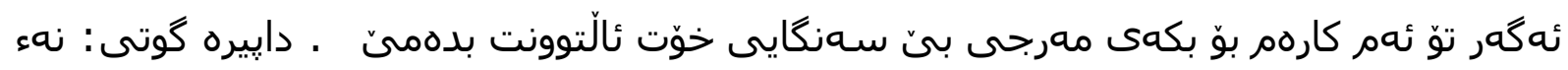

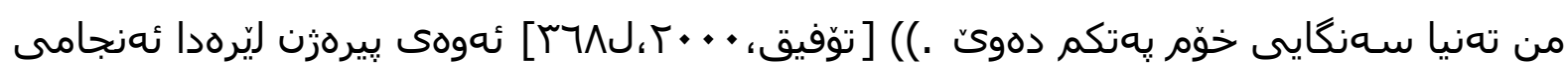

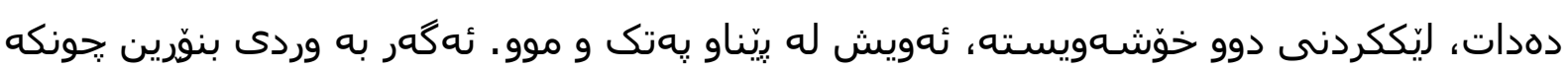

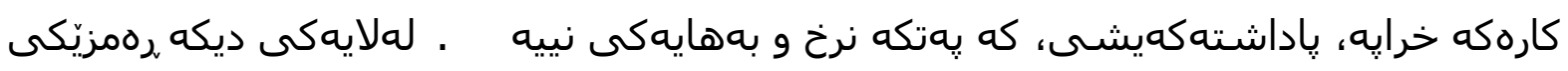

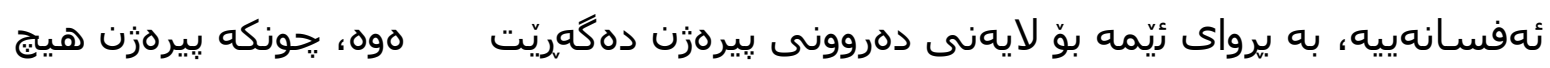

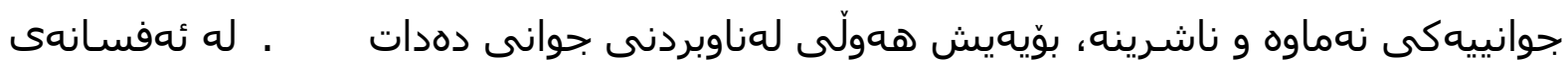

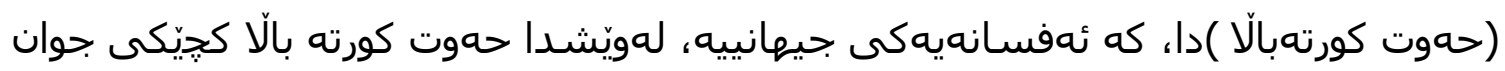




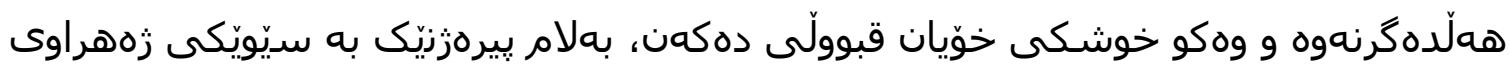

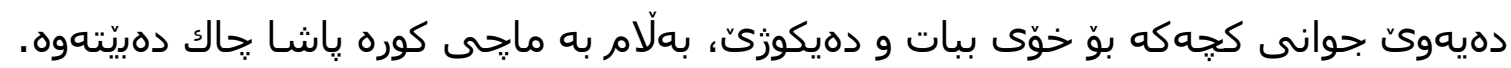
ج. ردمزى ئايينى

ردنكه ئايين كهورهترين كاريكهرى لهسهر همقايهتى فوّلكلوّريى كوردى ههبيت، :جونكه همقايهتى فوّلكلوّريى، همقايهتخوانهكانى له كهسانى ئاسايى و نهخويْندهوارن و زووترين

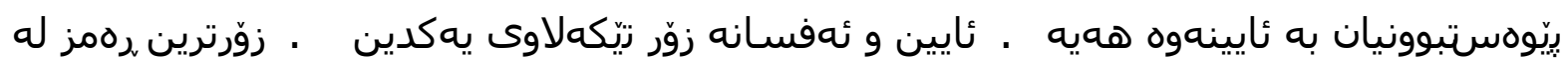

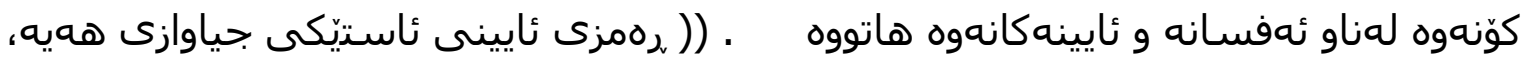
ئامانجى ئهوهيه مروّق بكاته سـيستهميكى سـرهوهى سـرووشت، يا ئهوديو سـرووشت، جكَه

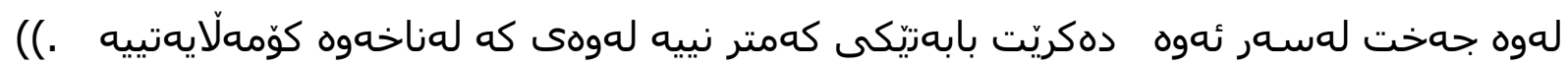

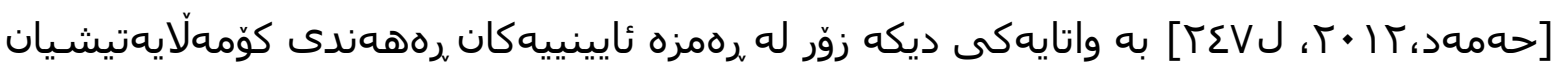

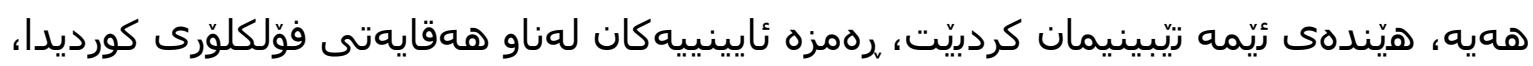

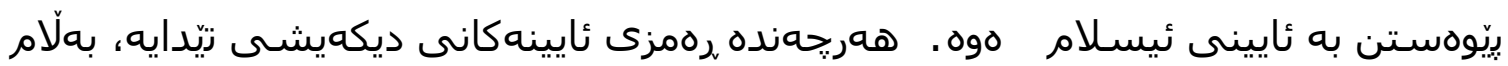

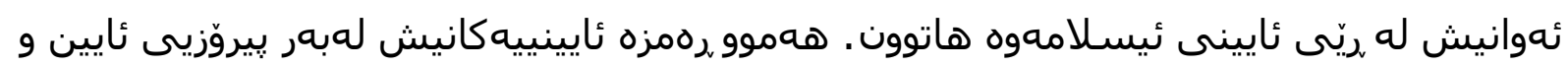

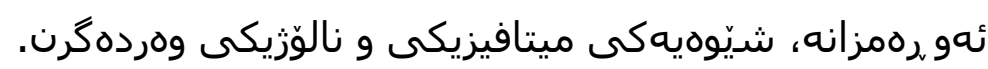

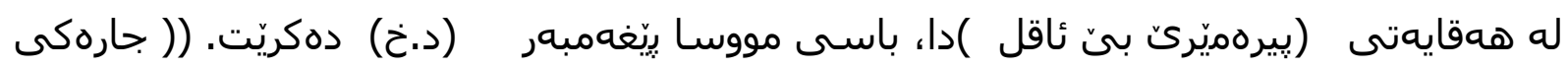

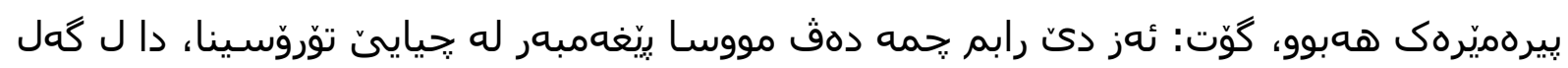

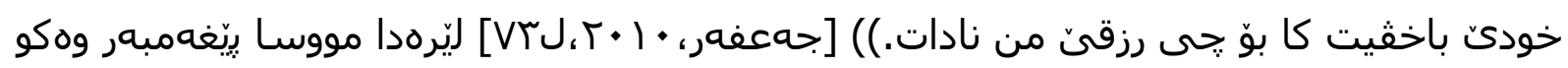

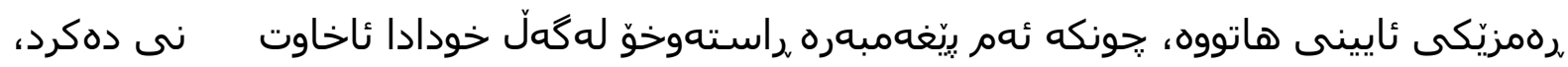

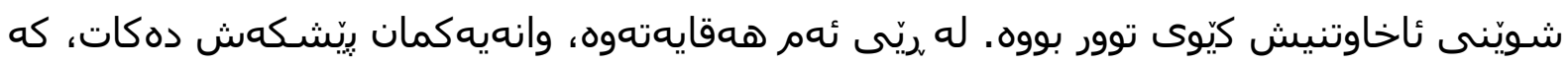

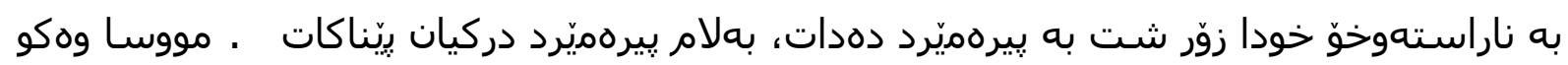

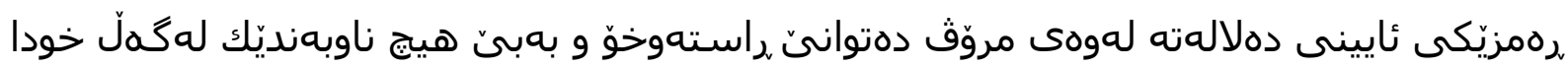
بيهيثيّت، هوروهك خودا له قورئانيش ئامازرى بهوهى كردووه، كه له شادهمارى ملتانهوه نزيكترم لِيتان.

له ههقايهتى (بهسه هاتى جوولهكه)دا، جوولهكه وهكو رهمزيّكى ئايينى بوّ ئايين و كهسانى

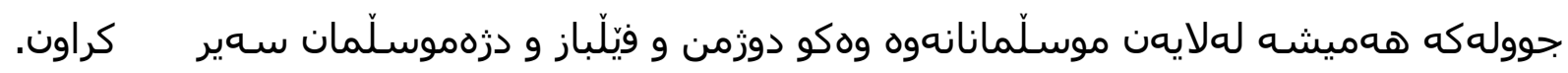

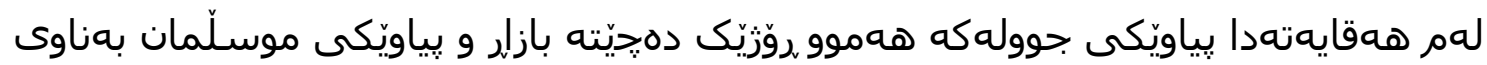

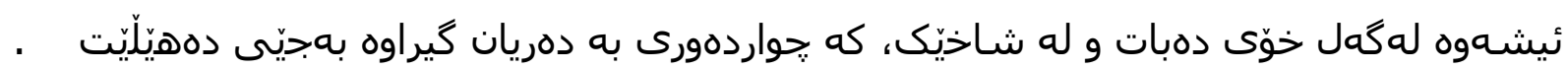

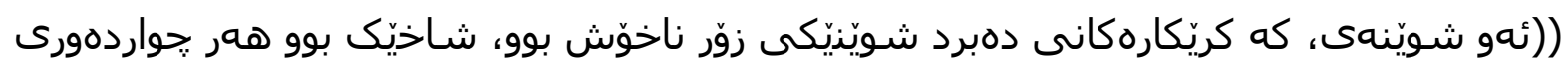

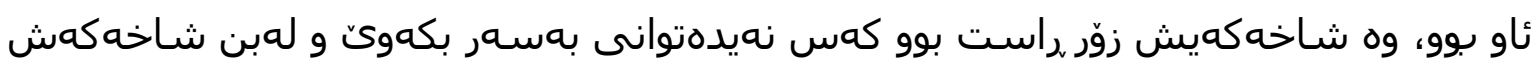

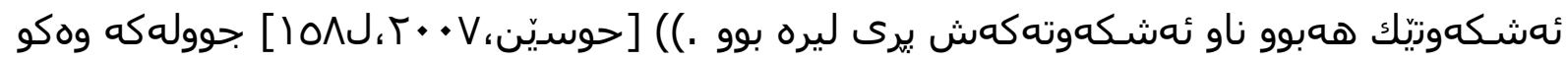

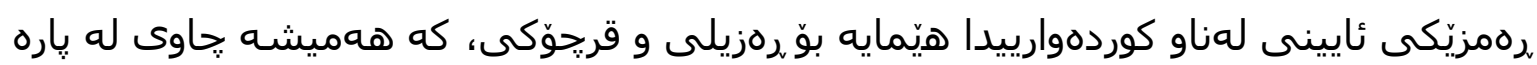

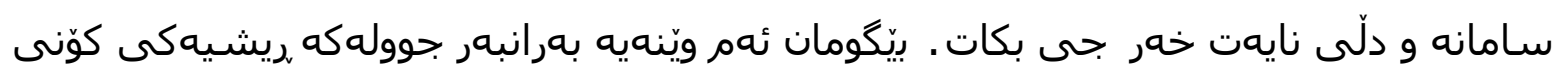


ههيه، تهنانهت لهناو ئايينى مهسيحيش ههبووه باشترين نموونهمان دهقى بازرگانى

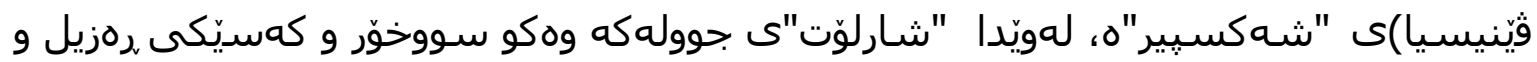
خهراي ويّناكراوه، كه يارهكانى له هaموو شت خوّشتر

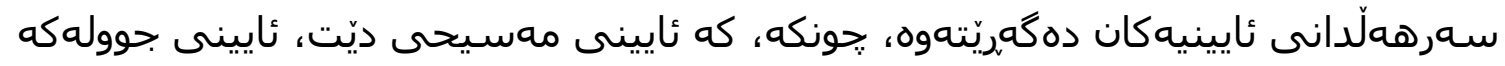
هوبووه و مهسيحييهت ئهم ئايينه رهتدهكاتهوه، كه ئيسلام ديّت، همردوو ئايينى جوولهكه و

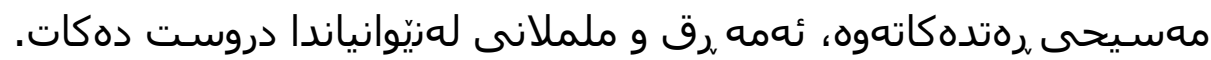
له رهمزى ئايينيدا نابى روّلّى كتيّبه ئاسمانييهكانى وهكو تهورات و ئينجيل و قورئان لهبير بكهين .

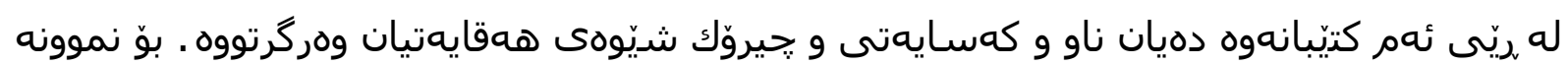

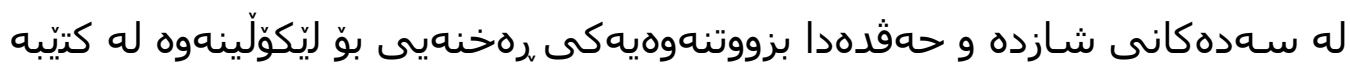

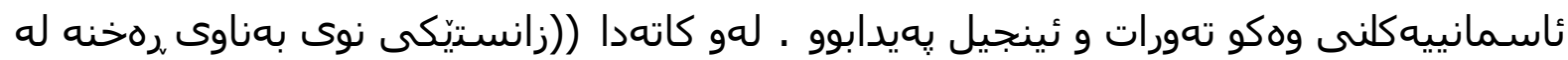

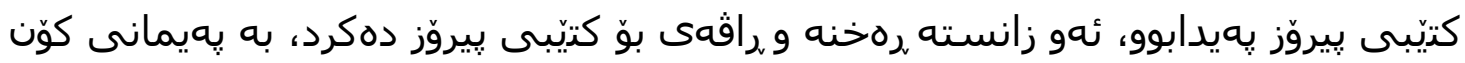

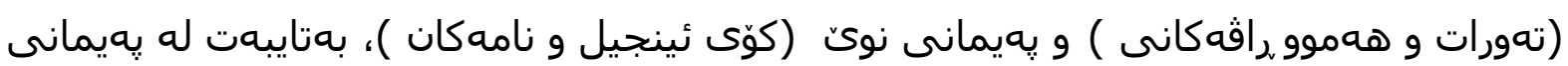

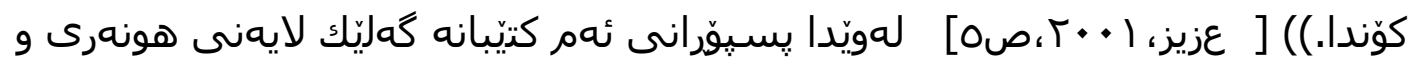

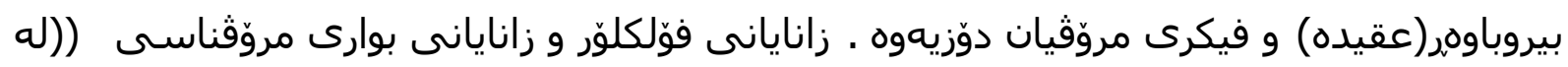
تويّزينهوهكانياندا له يهيمانى كوّن گهلى لايهنى بيروباوهر و دابونهريتى ميللييان دوّزيهوه و بوّا سهر:جاوه يهكمركهيان گهراندهوه، هاوكات تويّزينهوهيان له ههندى فوّرمى ئهدهبى فوّلكلوّرييدا

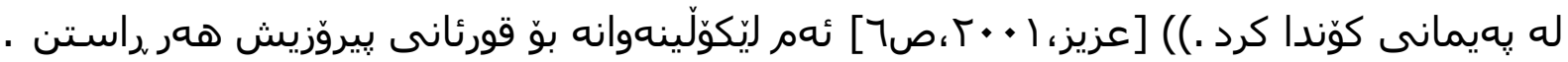

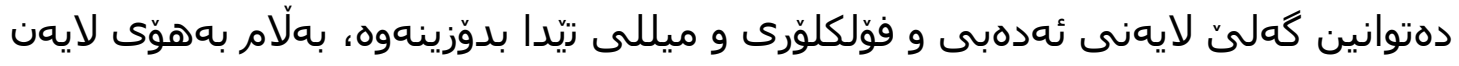

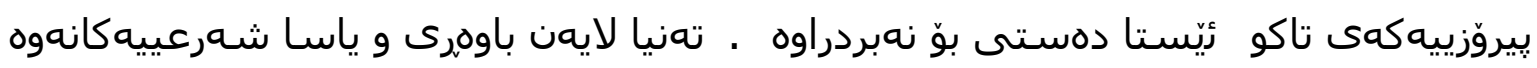

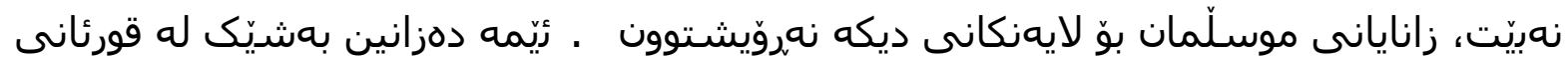

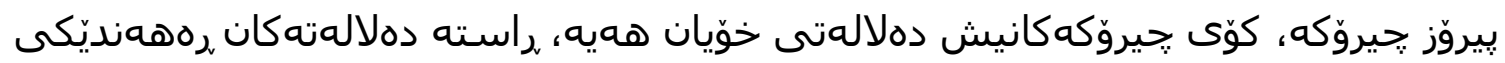

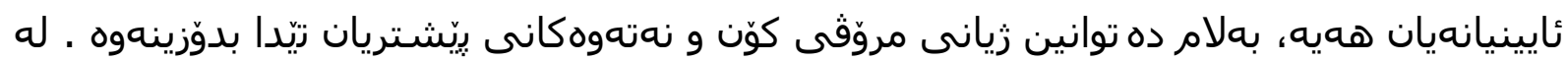

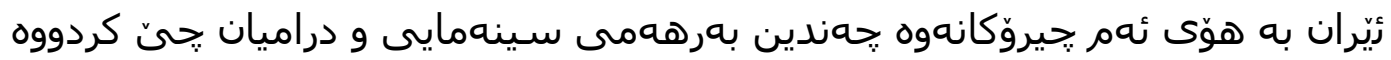

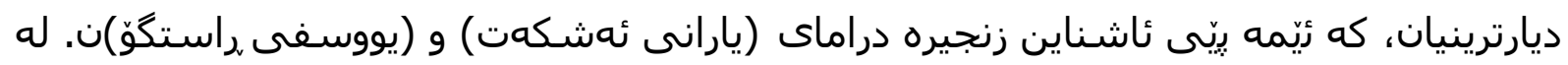

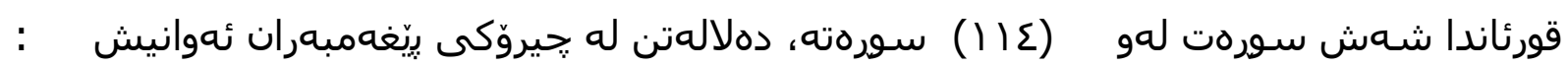
يوونس، هوود، يووسف، ئيبراهيم، محهمهد، نووح . ㅈهند سوورهزيّكى تريش ههن، جحيروّكن و

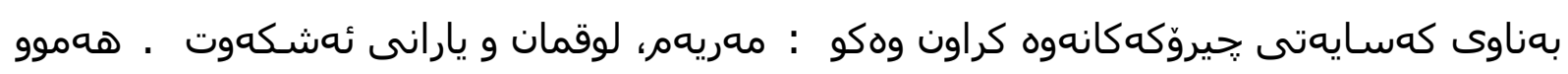
ئهمانه به زيّيه,رينى كات دهبنه رهمز و خوّيان دهخزيننه ناو كَيرانهوهيان كُورانى بهسهردا ديّت. 


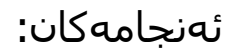

ا . شيعرييهت و سيموّلوّزيا بِيِوهندييهكى يتهو لهزيّوانياندا ههيه، جِونكه ههردووكيان بِيِوهندن به يرسـ زمان و دهلالهتوه.

ז. رهمز بههوّى جياوازبوونى له مهغزايهكى ههميشه تووشى ليّلَى و نارووونيم ان دهكات. ئهم

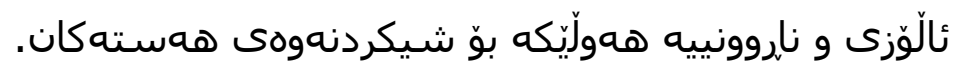

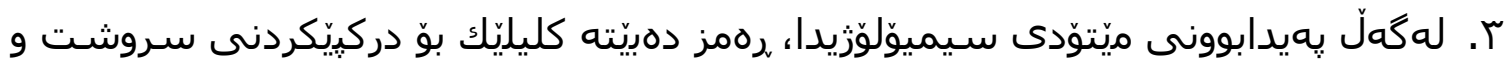
بوونى مروّث . دهبينين ئهمه له ههقايهتى فوّلكلوّريدا تهواو رهنكى داوهتهوه، كهواته بوّ

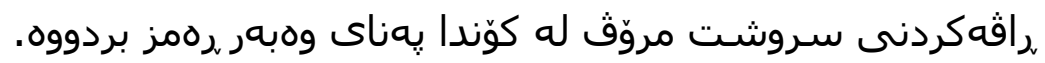

ع. كهسايهتييه ميّزووييهكان ج بيانى و ج كورد له زوّر ههقايهتى فوّلكلوّرييدا ئامازَهيان بوّ كراوه .

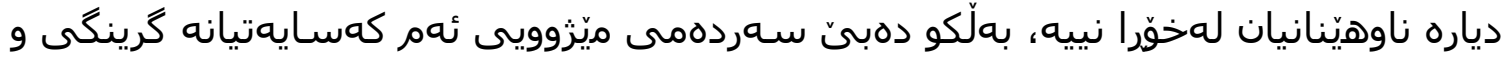
بايهخى نهتهوهيى و ميّزوويييان همبريت.

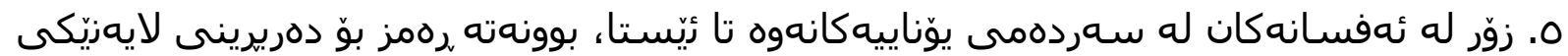
زيان، ئهفسانهيش له كوّى بوارهكانى زياندا وهكو ئايينى، ميزروويى، ئهدهبى...تاد ههن.

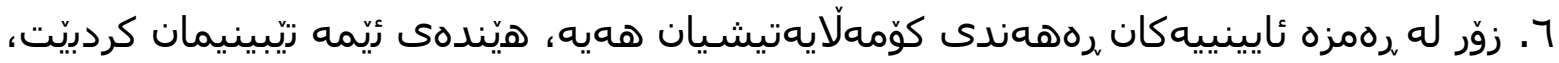

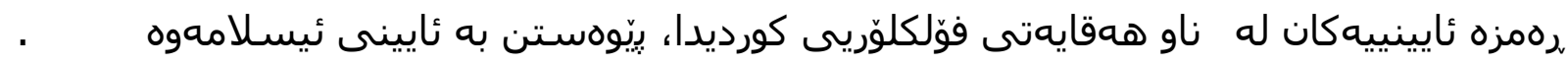

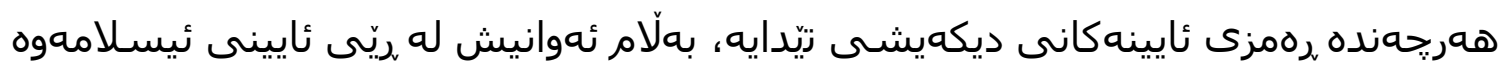

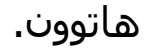

سمريحاوهكان:

به زمانى كوردى

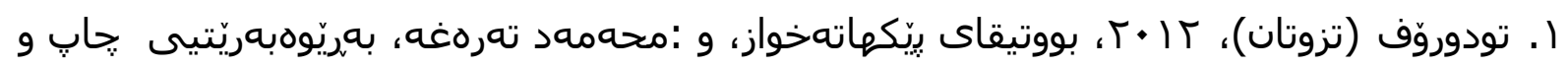

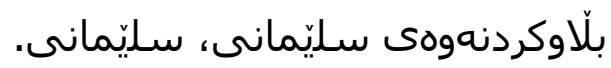

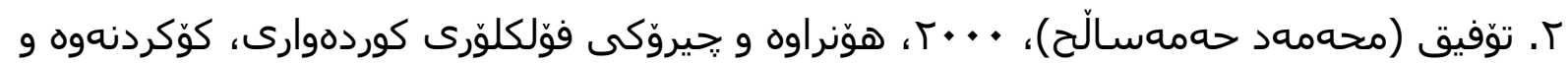

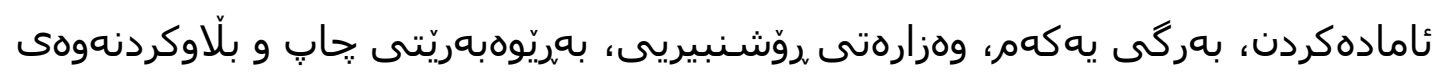
سليّمانى، سـليّمانى.

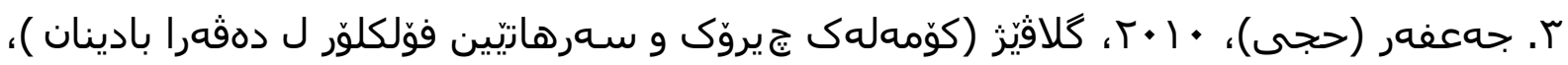
ئهنستيتوتا كهلهيوورى كوردى، دهوّك.

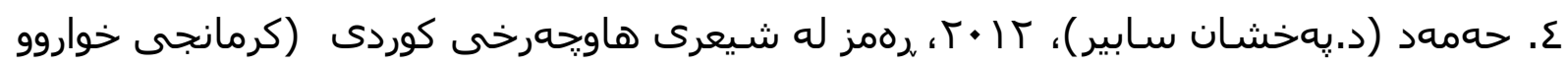
(99) / (199V. 


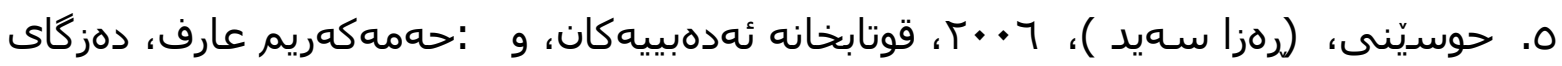
موكريان، هموليّر.

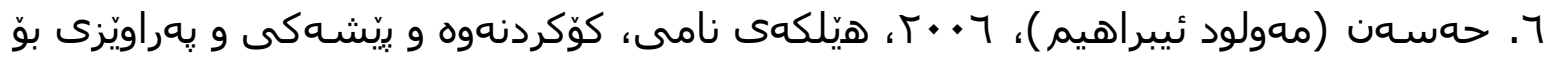
نووسيوه، بهرگى يهكهر، بهشى دووهر، ئهنستيوتى كهلهيوورى كوردى، هـوليّر.

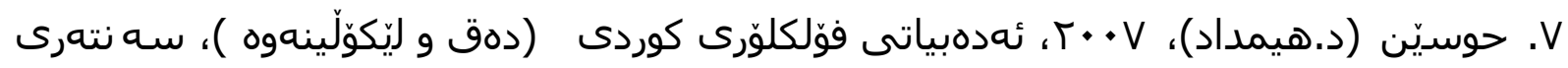
،رووناكبيريى همتاو، ههوليّر.

^. خوّشـناو (هيّمن عومهر)، • ( • ؟، شيعرييهتى دهقى جحيروّكى كوردى،وهزارهتى ،ووّـنبيريى، هموليّر.

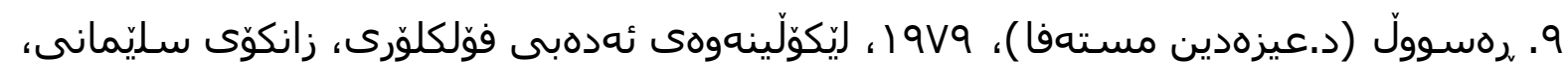

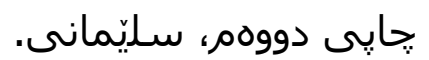

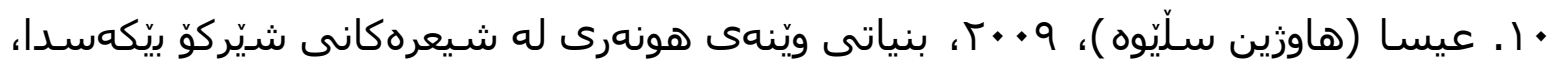
دهزكاى سهردهرم، سليّمانى.

I ا. كَردى (عهزيز)، عا • ז، سـ دهرمان (هaقايهتى كوردهوارى)، كوّكردنهوه و ئامادهكردن، ناوهندى ئاويّر، هموليّر.

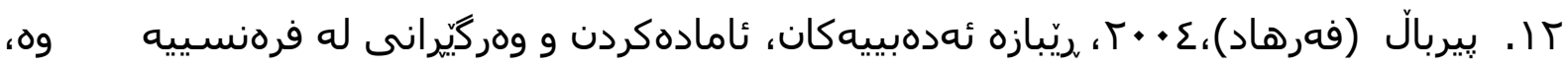
دهزگاى ئاراس، هموليّر.

بa زمانى عaرoبى:

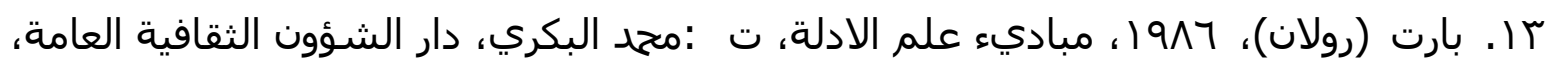

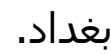

ع ا. دي سوسيير (فرديناند)، 9/1، ، علم اللغة العام، ت :يوئيل يوسف عزيز، مراجعة : مالك يوسف المطلبي، دار الافاق العربية، بغداد.

ه ـ الزواوي (بغورة)، V • • †، العلامة والرمز في الفلسفة المعاصرة، مجلة عالم الفكر، عدد:؟.

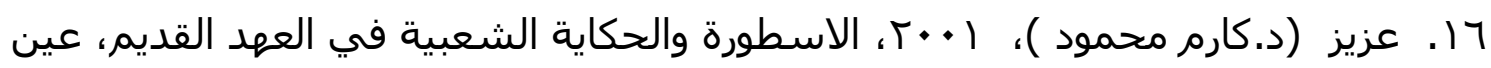
للدراسات والبحوث الانسانية والاجتماعية، المصر.

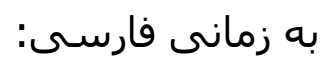

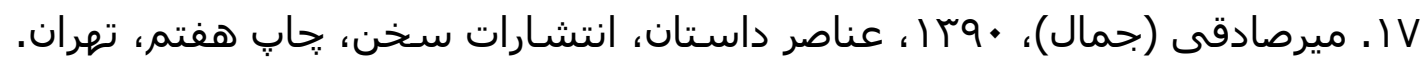




\section{REFERENCES}

Aziz, Karim Mahmoud, (2001). Myth and Folk Tales of the Old Testament, Ain for Human and Social Studies and Research, Egypt.

Bart, Roland, (1986). Principles of Evidence, Translation from: Mohammed Bakri, House of Public Cultural Affairs, Baghdad.

Birbal, Farhad, (2004). Literary Schools, Translation from French, Aras Printing and Publishing House, Erbil.

De Sussier, Ferdinand, (1985). General Linguistics, Translation from: Yoel Youssef Aziz, Review: Malik Yousef Al-Muttalibi, Dar Al-Afaq Al-Arabiya, Baghdad.

Jaafar, Haji, (2010).Galavizh (collection of the folk tale of Behdinan), the Kurdish Heritage Institute, Dohuk.

Gardi,Aziz, (2014). Three medicine (Kurdish story), Awer Printing and Publishing House, Erbil.

Hamad, Bakhshan Saber, (2012).The symbol of Kurdish poetry, Kurdish Academy, Erbil.

Hassan, Mouloud Ibrahim, (2006). Nami Egg, First Skin, Kurdish Heritage Institute, Erbil.

Hosseini, Raza Sayed, (2006). Literary schools, translated by: Hamakirim Aref, Mukiryani House for Printing and Publishing, Erbil.

Hussein, D. Hemedad, (2007). Kurdish Folklore Literature, Cultural Center Hattau, Erbil.

Issa, Hawzhin Slewa, (2009). Structure of poetic image in poetry Sherko Bekas, Sardam Printing and Publishing House, Sulaimani.

Mirsadqi, Jamal, (1390), Elements of the Story, Sahkun House of Public, Seventh Edition, Tehran

Tawfiq,Muhammad Saleh, (2000). Kurdish folklore poetry and story, first skin, Ministry of Culture, Sulaimani Directorate for Publishing and Distribution.

Zouaoui, Bagoura, (2007).The mark and symbol in contemporary philosophy, the world of thought magazine, number: 3 . 